Article

\title{
Investigation of Escherichia coli O157:H7 Survival and Interaction with Meal Components during Gastrointestinal Digestion
}

\author{
Diane de La Pomelie ${ }^{1,2}$, Sabine Leroy ${ }^{1}$, Régine Talon ${ }^{1}$, Philippe Ruiz ${ }^{1} \mathbb{D}$, Philippe Gatellier ${ }^{2}$ \\ and Véronique Santé-Lhoutellier $2, *$ (i) \\ 1 Université Clermont Auvergne, INRAE, MEDIS, 63000 Clermont-Ferrand, France; \\ dianedelapomelie@yahoo.fr (D.d.L.P.); sabine.leroy@inrae.fr (S.L.); regine.talon@inrae.fr (R.T.); \\ philippe.ruiz@inrae.fr (P.R.) \\ 2 INRAE, UR 370 QuaPA, 63122 Saint-Genès-Champanelle, France; philippe.gatellier@inrae.fr \\ * Correspondence: veronique.sante-lhoutellier@inrae.fr
}

Citation: de La Pomelie, D.; Leroy, S.; Talon, R.; Ruiz, P.; Gatellier, P.; Santé-Lhoutellier, V. Investigation of Escherichia coli O157:H7 Survival and Interaction with Meal Components during Gastrointestinal Digestion. Foods 2021, 10, 2415. https:/ / doi.org/10.3390/foods10102415

Received: 18 June 2021

Accepted: 8 October 2021

Published: 12 October 2021

Publisher's Note: MDPI stays neutral with regard to jurisdictional claims in published maps and institutional affiliations.

Copyright: (c) 2021 by the authors. Licensee MDPI, Basel, Switzerland. This article is an open access article distributed under the terms and conditions of the Creative Commons Attribution (CC BY) license (https:// creativecommons.org/licenses/by/ $4.0 /)$

\begin{abstract}
Escherichia coli O157:H7 is responsible for foodborne poisoning, incriminating contaminated animal food and especially beef meat. This species can survive in the digestive tract, but, up to now, very few studies have considered its survival during the gastrointestinal digestion of meat. The present study aimed to investigate the survival of the pathogenic strain E. coli O157:H7 CM454 during the gastrointestinal digestion of ground beef meat and its interactions with meal components using a semidynamic digestive model. The CM454 strain in meat survived throughout digestion despite acidic $\mathrm{pH}(\mathrm{pH} 2)$ and the presence of bile salts. The addition of nitrite and ascorbate in the digestion medium led to a decrease in strain survival. During digestion, a release of free iron was observed, which was accentuated in the presence of the CM454 strain. In addition, the strain modified the $\mathrm{Fe}^{2+} / \mathrm{Fe}^{3+}$ ratio, in favor of $\mathrm{Fe}^{2+}$ compared to the noninoculated meat sample. In the presence of nitrite, nitroso compounds such as nitrosamines, nitrosothiols, and nitrosylheme were formed. E. coli O157:H7 CM454 had no impact on N-nitrosation but seemed to decrease S-nitrosation and nitrosylation.
\end{abstract}

Keywords: Shiga toxin-producing Escherichia coli; ground meat; gastrointestinal digestion; nitrite; nitroso compounds

\section{Introduction}

Shiga toxin-producing Escherichia coli (STEC) are zoonotic agents that rank third among food-borne pathogens regarding their incidence and dangerousness in the European Union [1]. They are responsible for foodborne poisoning incriminating contaminated animal food products, vegetables, and watery drinks [1]. STEC, such as E. coli O157:H7, are considered to be a severe public health concern due to their low infection dose (10-100 CFU) and because of the seriousness of the syndromes caused, related, in particular, to their production of Shiga toxins [1-3]. Ruminants, especially beef cattle, are the primary reservoir of STEC and their feces are considered the main source of STEC contamination of carcasses in slaughterhouses and, therefore, of meat $[4,5]$. The consumption of bovine meat and products thereof accounted for $24 \%$ of epidemics caused by STEC in Europe in the period 2012-2017 [1]. According to an Ifop survey published in 2010, ground beef is considered the favorite meat product of children at $59 \%$ and can constitute a danger in the event of insufficient cooking (under $70^{\circ} \mathrm{C}$ ) of contaminated meat [6].

The survival of STEC after the ingestion of contaminated food throughout the human digestive tract depends on numerous factors and is not yet fully understood [7]. What is known is that E. coli O157:H7 can tolerate acidic $\mathrm{pH}$ values such as those found in the harsh stomachal environment ( $\mathrm{pH} 1.5$ to 3) [8]. Five acid resistance systems have been 
identified in STEC that allow them to resist a range of acidic $\mathrm{pH}[9,10]$. The TIM (TNO gastrointestinal Model), which includes the stomach, duodenum, jejunum, and ileum, has been used to study the survival of E. coli O157:H7 in several homogenized and fluidized food matrixes such as ground meat, fermented olives, and cheese. The survival of E. coli O157:H7 was very low in the stomach and duodenum, while its transit through the distal parts (jejunum and ileum) resulted in an increase in the pathogenic population [11-13]. The survival could be impacted by the composition of the food matrix and its chemical transformation during digestion.

Indeed, the physicochemical environment of the stomach triggers chemical reactions, mainly oxidation, that can start during meat storage, namely the production of reactive oxygen species (ROS), leading to protein and lipid oxidation, further propagated during digestion [14-17]. The stomach environment enhances oxidation, due to its low $\mathrm{pH}$ and still dissolved oxygen content [18].

However, it should be considered that meat is part of a meal often accompanied by vegetables rich in vitamins and antioxidants. It has been established that vitamin $C$ (or ascorbate) content can reach $1 \mathrm{mM}$ in plant foods [19]. Moreover, when consuming vegetables, the significant input of nitrate should be taken into account, which is partly reduced into nitrite by endogenous buccal bacteria [20]. Therefore, vegetables containing around $400 \mathrm{mg} / \mathrm{kg}$ of nitrate will give approximately $60 \mathrm{mg} / \mathrm{kg}$ of equivalent nitrite or $1 \mathrm{mM}$ in nitrite [21]. Under the acidic conditions of the stomach and in the presence of ascorbic acid (reduction medium), nitrite is reduced to NO (nitric oxide). Regarding chemical reactions, NO not only reacts with amino acids containing thiols and secondary amine groups, leading to the formation of nitrosothiols (S-nitrosation) and nitrosamines (Nnitrosation), respectively, but also with heme iron, leading to the formation of nitrosylheme (nitrosylation) [22]. Moreover, free iron present in meat can act as a powerful catalyst of oxidation and $\mathrm{N}$-nitrosation during digestion [23].

Up to now, neither the survival during digestion of the pathogen E. coli O157:H7 in a complex meal nor its interaction with the macro and micronutrients present has been studied. The aim of this work was to investigate the survival of this pathogenic bacterium considering the chemistry of the meal components. To this end, a semidynamic digestive model representing the stomach and global intestinal compartments was set-up. The meal studied contained meat and nitrite/ascorbate content in a similar concentration to that occurring when eating vegetables.

\section{Materials and Methods}

\subsection{Meat Samples}

The reagents are listed in Supplementary Data S1. To avoid any animal effect, all the experiments were carried out on the two triceps brachii muscles from the same Charolais heifer. After 2 weeks of ageing under vacuum, the muscles were surface-sterilized using a Hot Air Gun $\left(\mathrm{BOSCH}^{\circledR}\right)$, then trimmed to $5 \mathrm{~mm}$ thickness. The meat was ground using 8 $\mathrm{mm}$-hole mincers to mimic a bolus after chewing [24]. The meat bolus sample was used to perform protein and lipid assays according to the methods of Dumas [25] and Folch [26], respectively. The percentage of protein in meat was $20.8 \pm 1.2 \%$, while that of lipid was $0.2 \pm 0.1 \%$. The meat bolus samples were vacuum-packed in portions of $150 \mathrm{~g}$ and then frozen at $-80{ }^{\circ} \mathrm{C}$ until use. For each experiment, the meat bolus was thawed at $+4{ }^{\circ} \mathrm{C}$ overnight.

\subsection{Strain Culture and Inoculation of Meat}

The experiments were carried out using a nontoxigenic E. coli O157:H7 EDL933 $\Delta$ stx strain called CM454 that possesses a kanamycin resistance cassette [27]. The strain was cultivated in $3 \times 100 \mathrm{~mL}$ of BHI medium (DIFCO ${ }^{\mathrm{TM}}$, France), in $100 \mathrm{~mL}$ Erlenmeyer flasks with screw caps, under low oxygenation and agitation $(100 \mathrm{rpm})$ at $39^{\circ} \mathrm{C}$ (temperature of cattle digestive tract, in which this bacterium is frequently found). The three flasks of culture were pooled when an optical density (OD) of 0.6 of the culture was reached. The 
culture was centrifuged $\left(8000 \mathrm{rpm}, 5 \mathrm{~min}, 4^{\circ} \mathrm{C}\right.$ ) and the pellet rinsed and resuspended in $1.5 \mathrm{~mL}$ of physiological saline and kept on ice before inoculation in the meat bolus.

Each meat bolus sample of $150 \mathrm{~g}$ was inoculated with the $1.5 \mathrm{~mL}$ bacterial suspension to obtain an initial inoculation of $9 \log \mathrm{CFU} / \mathrm{g}$. The control meat bolus sample was prepared by adding $1.5 \mathrm{~mL}$ of sterile physiological saline. Each meat bolus sample-contaminated or not with the bacterial strain-was shaped to obtain a patty, which was placed on polystyrene trays, under an oxygen-permeable stretch film, and stored for 3 days at $4{ }^{\circ} \mathrm{C}$.

\subsection{In Vitro Batch Digestion Model of Meat Bolus and Sampling}

The digestions ( $n=3$ per condition, control and EHEC, and time) were performed with an in vitro batch system, composed of five glass Erlenmeyer flasks of $100 \mathrm{~mL}$ (Supplementary Data S2). The first four flasks represented the stomach and the last one represented the intestinal compartment. The parameters ( $\mathrm{pH}$ and enzyme content) were chosen to accurately reproduce human digestion from children to adults [28]. The temperature was kept constant at $37^{\circ} \mathrm{C}$. For each Erlenmeyer flask, there was a rotating system (100 rpm bar magnet), which mimicked stomach peristaltism and kept the bolus homogeneous.

In the gastric compartment, $50 \mathrm{~mL}$ of simulated gastric fluid (SGF) was added (KCl $6.9 \mathrm{mM}, \mathrm{NaCl} 47.2 \mathrm{mM}, \mathrm{CaCl}_{2} 0.15 \mathrm{mM}, \mathrm{KH}_{2} \mathrm{PO}_{4} 0.9 \mathrm{mM}, \mathrm{NaHCO}_{3} 25 \mathrm{mM}, \mathrm{MgCl}_{2} 0.1 \mathrm{mM}$, and $\left.\left(\mathrm{NH}_{4}\right)_{2} \mathrm{CO}_{3} 0.5 \mathrm{mM}\right)$ and the $\mathrm{pH}$ was adjusted to 2, according to the international consensus on digestion described by Minekus et al. (2014) [29]. After the addition of $10 \mathrm{~g}$ of meat, whose temperature had been raised previously to $12 \pm 1^{\circ} \mathrm{C}$, the $\mathrm{pH}$ rose to 5 in a few minutes, due to the buffering capacity of the meat. The first sample, labeled $\mathrm{t} 0 / \mathrm{pH} 5$, was obtained after the $\mathrm{pH}$ rose to 5 , just before enzyme addition. For the other gastric samples, pepsin porcine gastric mucosa (Sigma-Aldrich, France) was added $(2000 \mathrm{U} / \mathrm{mL}$ ) and the gastric $\mathrm{pH}$ was lowered step by step by adding $\mathrm{HCl} 37 \%$ from $\mathrm{pH} 5$ (initial $\mathrm{pH}$ of the meat in the gastric fluid) to $\mathrm{pH} 2$ in $120 \mathrm{~min}$. The second sample, labeled t40/pH4, was obtained forty minutes after the $\mathrm{pH}$ dropped to 4 . The third sample, labeled $\mathrm{t} 80 / \mathrm{pH} 3$, was obtained forty minutes after the $\mathrm{pH}$ dropped to 3; and the fourth sample, labeled $\mathrm{t} 120 / \mathrm{pH} 2$, was obtained forty minutes after the $\mathrm{pH}$ dropped to 2 .

In the intestinal compartment, the $\mathrm{pH}$ value was increased to 7 by adding $0.39 \%$ $(v / v)$ of $\mathrm{NaOH} 10 \mathrm{~N}$. Bile salts $(50 \%$ cholic acid and $50 \%$ deoxycholic acid sodium salt mixture, Sigma-Aldrich, France) were added for a final concentration of $10 \mathrm{mM}$ in the final mixture [29]. In addition, intestinal enzymes (Sigma-Aldrich, France) were added, namely trypsin $(100 \mathrm{U} / \mathrm{mL})$, chymotrypsin type II $(25 \mathrm{U} / \mathrm{mL})$, and intestinal lipase type II from a porcine pancreas $(2000 \mathrm{U} / \mathrm{mL})$. Digestion in the intestinal compartment lasted $120 \mathrm{~min}$ and the last sample was labeled t240/pH7.

In parallel, to reproduce a more complex meal, sodium nitrite $(1 \mathrm{mM})$ and sodium ascorbate $(1 \mathrm{mM})$, the concentrations found in vegetables, were added in flasks containing meat and after the $\mathrm{pH}$ rose to 5 . Then, the same digestion protocol as that applied to the meat sample was used.

To sum up, two sets of gastro-intestinal digestion were carried out: meat contaminated or not with E. coli O157:H7 CM454; meat with nitrite/ascorbate contaminated or not with E. coli O157:H7 CM454. These sets of digestion were carried out in three independent replicates.

Four samples were taken: $\mathrm{t} 0 / \mathrm{pH} 5, \mathrm{t} 40 / \mathrm{pH} 4, \mathrm{t} 80 / \mathrm{pH} 3$, and $\mathrm{t} 120 / \mathrm{pH} 2$ for the gastric compartment. One sample was taken for the intestinal compartment: $\mathrm{t} 240 / \mathrm{pH}$. At each digestion time, the Erlenmeyer flask contents were homogenized in stomacher bags with a filter $(>250 \mu \mathrm{m})$ by mixing with a Stomacher double paddle blender (INTERSCIENCE BagMixer $\left.^{\circledR} 400\right)$ for $1 \mathrm{~min}$. The filtered digestates were collected and kept on ice for microbiological analyses or frozen at $-80^{\circ} \mathrm{C}$ for biochemical measurements.

\subsection{Bacterial Enumeration}

The initial microbiological quality of meat was controlled by enumerating the following: the total bacterial population on PCA medium (Difco ${ }^{\mathrm{TM}}$, Lyon, France) incubated at 
$30^{\circ} \mathrm{C}$ for $72 \mathrm{~h}$; lactic acid bacteria on MRS medium (Sigma-Aldrich, Illkirch, France) supplemented with nalidixic acid ( $40 \mathrm{mg} / \mathrm{L}$ ) to inhibit Gram-negative bacteria and Delvocid (200 mg/L) to inhibit yeast and mold incubated at $25^{\circ} \mathrm{C}$ for $72 \mathrm{~h}$ in a modified atmosphere jar (Anaerocult ${ }^{\circledR}$ A, Lyon, Merck); E. coli on CHROMagar ${ }^{\mathrm{TM}} \mathrm{O} 157$ medium (Thermofisher, Saint Quentin Fallavier, France) incubated for $24 \mathrm{~h}$ at $37^{\circ} \mathrm{C}$; and kanamycin-resistant bacteria on BHI-kanamycin medium ( $50 \mu \mathrm{g} / \mathrm{mL}$, Sigma-Aldrich, Illkirch, France) incubated for $24 \mathrm{~h}$ at $37^{\circ} \mathrm{C}$. To follow the survival of the $\mathrm{CM} 454$ strain during digestions, enumeration was carried out on BHI-kanamycin medium incubated for $24 \mathrm{~h}$ at $37^{\circ} \mathrm{C}$ after appropriate serial dilutions.

\subsection{Biochemical Analyses}

\subsubsection{Protein Digestion Measurement}

Protein digestion was determined by the fluorescamine method, which allows measurement of the free $-\mathrm{NH}_{2}$ groups from peptides and amino acids. The proteins were precipitated with cold trichloroacetic acid (15\% final concentration) according to Sayd et al. (2016) to work only on released amino acids and peptides [30]. Fluorescamine (Sigma-Aldrich, Illkirch, France) is a fluorescent probe specific to the primary amine group ( $\mathrm{N}$-terminal $\alpha$-amino group) of peptides and free amino acids [31]. The amine-fluorescamine complex, excited at $375 \mathrm{~nm}$, emits at a wavelength of $475 \mathrm{~nm}$. The standard is provided with a glycine solution. Thus, the level of peptides was expressed in millimolar (mM) equivalent glycine. The fluorescence measurements were performed with a Jasco FP-8300 spectrofluorometer.

\subsubsection{Oxidation Measurement of Proteins and Lipids}

The oxidation of the proteins from the digestate was evaluated by measuring the carbonyl groups, according to the method of Oliver et al. (1987) [32]. Carbonyl groups were detected by reaction with 2,4 dinitrophenylhydrazine (DNPH) (Sigma-Aldrich, Illkirch, France) which form protein hydrazones. The results were expressed as nanomoles of DNPH fixed per milligram of protein.

Lipid oxidation was measured by the thiobarbituric acid reactive substances (TBARS) method according to Lynch and Frei (1993) [33]. The results were expressed as nanomoles of equivalent malondialdehyde (MDA) per microliter.

\subsubsection{Determination of Free Iron Content and Its Oxidation State}

Free nonheme iron from samples was transformed to heme iron by a centrifugation method using a Vivaspin ${ }^{\circledR} 2$ system (PES membrane with a cut-off of $5 \mathrm{kDa}$ ). Centrifugation $(3800 \mathrm{~g} / \mathrm{h})$ was performed with a SL-40R centrifuge from Thermo Scientific. According to the Stolze method (1996) [34], the ratio of free iron content and $\mathrm{Fe}^{2+} / \mathrm{Fe}^{3+}$ forms was measured. Only the $\mathrm{Fe}^{2+}$ form could be linked with ferrozine reagent and formed a purplecolored complex with an absorbance at $540 \mathrm{~nm}$. In the presence of reducing conditions with ascorbate addition, the total free iron was in $\mathrm{Fe}^{2+}$ form. Thus, we obtained the total iron content. Conversely, in the absence of ascorbate, the content in $\mathrm{Fe}^{2+}$ form was determined, and the content in $\mathrm{Fe}^{3+}$ form was obtained by subtraction. Absorbance measurements were performed in 96-well microplates with a Hitachi U-5100 spectrometer.

\subsubsection{Ascorbate Content and Its State of Oxidation}

Total ascorbate content and the two forms of ascorbate (oxidized and reduced) were evaluated in the digestates by the method of Vislisel, Schafer, and Buettner (2007) [35]. In the presence of Tempol (4-hydroxy-2,2,6,6-tetramethylpiperidinyloxy) (Sigma-Aldrich, Illkirch, France), ascorbate was oxidized into dehydroascorbate (DHA), which then reacted with ophenylenediamine (OPDA) (Sigma-Aldrich, Illkirch, France) to form the fluorescent OPDADHA complex. In the absence of Tempol, only the naturally oxidized ascorbate present in the medium could react with OPDA. The difference between the two measurements gave the level of reduced ascorbate. The fluorescence of the OPDA-DHA complex was 
measured in 96-well black polystyrene microplates with a Jasco FP-8300 spectrofluorometer $\left(\lambda_{\mathrm{ex}}=375 \mathrm{~nm}\right.$ and $\left.\lambda_{\mathrm{em}}=475 \mathrm{~nm}\right)$.

\subsubsection{Nitrite and Nitrate Content}

Nitrite $\mathrm{NO}_{2}{ }^{-}$and nitrate $\mathrm{NO}_{3}{ }^{-}$contents were determined using the Griess reaction with a Sigma-Aldrich colorimetric assay kit (Sigma-Aldrich, Illkirch, France).

\subsubsection{Nitrosothiols and Nonvolatile Nitrosamine Contents}

Nitrosothiols and nonvolatile nitrosamines were assessed according to the protocol of Bonifacie et al. (2021) [36]. Briefly, sample $\mathrm{pH}$ was increased to reach $\mathrm{pH} 8$ with $\mathrm{NaOH}$ and to eliminate proteins and digestive enzymes, and the samples were centrifuged ( $3800 \mathrm{~g} /$ $30 \mathrm{~min}$ ) with a Vivaspin ${ }^{\circledR} 2$ system (PES membrane with a cut-off of $5 \mathrm{kDa}$ ). The assays were performed on filtrates. As mentioned in the previous paragraph, the initial contents of $\mathrm{NO}_{2}{ }^{-}$and $\mathrm{NO}_{3}{ }^{-}$were obtained on the filtrates using a Griess reaction colorimetric assay kit.

Nitrosothiol content was measured after saturating the samples with $\mathrm{HgCl}_{2}(40 \mathrm{mM})$, which specifically cleaves the S-NO bonds [36]. After filtration on $0.22 \mu \mathrm{m}$ regeneratedcellulose (RC) membranes, nitrite content was measured and the subtraction between post- $\mathrm{HgCl}_{2}$-treatment and initial contents provided the nitrosothiol content.

Nitrosamine content was measured after irradiating the samples using a UV-lamp (UVItec Cambridge LF-215S Filtered UV Lamps, $254 \mathrm{~nm}$ Wavelenght, $2 \times 15 \mathrm{~W}$ ). It was established that the photodegradation of nitrosamines $\mathrm{R}-\mathrm{N}=\mathrm{NO}$ and nitrosothiols R$\mathrm{S}=\mathrm{NO}$ with UV irradiation leads to $\mathrm{NO}_{2}{ }^{-}$and $\mathrm{NO}_{3}{ }^{-}$release [36]. The samples were irradiated for 15, 30, 60, and $120 \mathrm{~min}$. The $\mathrm{NO}_{2}{ }^{-}$and $\mathrm{NO}_{3}{ }^{-}$contents were measured at each irradiation time and the second-degree polynomial function curve $\mathrm{f}(1 / \mathrm{t})=\mathrm{a} *\left[\mathrm{NO}_{2}{ }^{-}\right.$ $\left.+\mathrm{NO}_{3}{ }^{-}\right]^{2}+\mathrm{b} *\left[\mathrm{NO}_{2}{ }^{-}+\mathrm{NO}_{3}{ }^{-}\right]^{2}+\mathrm{c}$ was drawn, the $\mathrm{c}$ value giving the maximum content of nitrosothiols + nitrosamines. The subtraction between this value and the nitrosothiol content (obtained with the $\mathrm{HgCl}_{2}$ treatment) provided the nonvolatile nitrosamine content.

\subsubsection{Determination of Heminic Iron and Nitrosylation}

Total heme iron content was determined in the form of acid hematin by extraction in acidic acetone [37] with a ratio of $80 \%$ acetone, $18 \%$ sample, and $2 \% \mathrm{HCl} 12 \mathrm{~N}$, and then filtrated on $0.22 \mu \mathrm{m} \mathrm{RC}$ membranes. The total heme iron content was evaluated by measuring the absorbance of the supernatant at $512 \mathrm{~nm}$, with an absorption coefficient of $9.52 \mathrm{mM}^{-1} \cdot \mathrm{cm}^{-1}$.

The nitrosylheme iron was extracted in acetone with a ratio of $80 \%$ acetone and $20 \%$ sample and then filtrated on $0.22 \mu \mathrm{m}$ RC membranes. The level of nitrosylheme in the filtrate was evaluated by measuring the specific absorbance at $540 \mathrm{~nm}$ with an absorption coefficient of $11.3 \mathrm{mM}^{-1} \cdot \mathrm{cm}^{-1}$. Absorbance measurements were performed on a Hitachi U-5100 spectrometer. Nitrosylation was expressed as the percentage of nitrosylheme to total heme iron.

\subsection{Statistical Analysis}

The values for each experimental condition are reported as the mean \pm standard derivation (sd) of 3 independent determinations. To assess the effect of the different variables (time and $\mathrm{pH}$ of digestion, inoculation with bacterial strain, nitrite and ascorbate addition), the data were analyzed by ANOVA with a linear mixed-effects model with lme4 and lmerTest $\mathrm{R}$ packages [38] taking into account the interaction between the two variables, time and inoculum (fixed effects). Biological replicates are considered random factors. The Restricted Maximum Likelihood (REML) approach was used to estimate parameters. A Tukey's post hoc test run at a $5 \%$ level of significance $(p<0.05)$ was performed after estimating the least-squares means with the emmeans R package [39]. A principal component analysis (PCA) was performed with the ade4 R package. All the statistical analyses were performed with $\mathrm{R}$ software. 


\section{Results}

3.1. E. coli O157:H7 CM454 Survival and Its Interaction with Meat Components throughout Digestion

\subsubsection{E. coli O157:H7 CM454 Survived throughout Meat Digestion}

The initial contamination of the meat samples after trimming, mincing, freezing, and thawing was low: $2.7 \log \mathrm{CFU} / \mathrm{g}$ of total bacteria and $2.6 \mathrm{log} \mathrm{CFU} / \mathrm{g}$ of lactic acid bacteria were enumerated. E. coli, E. coli serogroup O157, and kanamycin-resistant bacteria were not found.

The meat was inoculated at $9.8 \pm 0.2 \mathrm{log} \mathrm{CFU} / \mathrm{g}$ by the E. coli O157:H7 CM454 strain, and after storage for 3 days at $4{ }^{\circ} \mathrm{C}$ and $30 \mathrm{~min}$ at $20^{\circ} \mathrm{C}$ to reach $12{ }^{\circ} \mathrm{C}$, the enumeration was $8.6 \pm 0.4 \log \mathrm{CFU} / \mathrm{g}$. Then, the population of the strain was determined at different sampling times from the gastric compartment to the ileum (Table 1). The strain was enumerated after several minutes at $\mathrm{pH} 5$ in the gastric compartment, revealing $8.0 \pm 0.5 \log \mathrm{CFU} / \mathrm{mL}$ of gastric fluid. At the end of intestinal digestion, the bacterial population decreased to $6.7 \pm 0.1 \log \mathrm{CFU} / \mathrm{mL}$ of digestate. A percentage of $5 \%$ of the bacterial population was still alive at the end of digestion.

Table 1. Survival of E. coli O157:H7 CM454 along the meat digestion. Values are mean \pm standard deviation of 3 independent biological replicates. Different letters indicate significantly different values $(p<0.05)$.

\begin{tabular}{|c|c|c|c|c|c|}
\hline $\begin{array}{c}\text { Time } \\
\mathrm{min} / \mathrm{pH}\end{array}$ & t0/pH5 & $\mathrm{t} 40 / \mathrm{pH} 4$ & t80/pH3 & t120/pH2 & t240/pH7 \\
\hline $\log \mathrm{CFU} / \mathrm{mL}$ & $8.0 \pm 0.5^{a}$ & $7.9 \pm 0.4^{a}$ & $7.2 \pm 0.5^{\mathrm{a}, \mathrm{b}}$ & $6.7 \pm 0.8^{a, b}$ & $6.7 \pm 0.1^{b}$ \\
\hline
\end{tabular}

3.1.2. E. coli O157:H7 CM454 Had No Impact on Meat Protein Digestion, Contrary to Its Oxidation

In the gastric compartment, protein digestion kinetics assessed by free $-\mathrm{NH}_{2}$ release did not increase significantly (19.2 $\pm 1.5 \mathrm{mM}$ eq glycine at t0 / $\mathrm{pH} 5$ to $29.2 \pm 3.6$ at $\mathrm{t} 120 / \mathrm{pH} 2)$. At the end of intestinal digestion, peptide release reached $70.3 \pm 5.7 \mathrm{mM}$ eq glycine in the absence of E. coli O157:H7 CM454 and $62.3 \pm 4.9 \mathrm{mM}$ eq glycine in the presence of the strain. The final peptide content at $\mathrm{t} 240 / \mathrm{pH} 7$ was similar for the two meat digestions, with and without $E$. coli O157:H7 CM454.

Protein oxidation was determined by measuring carbonyls. The carbonyl content was $33.4 \pm 4.1 \mathrm{nmols} / \mathrm{mg}$ proteins at the beginning of digestion $\mathrm{t} 0 / \mathrm{pH} 5$ and remained stable throughout meat digestion: $30.9 \pm 4.6 \mathrm{nmol} / \mathrm{mg}$ protein at the end of gastric digestion $\mathrm{t} 120 / \mathrm{pH} 2$ and $32.9 \pm 5.2 \mathrm{nmol} / \mathrm{mg}$ protein at $\mathrm{t} 240 / \mathrm{pH}$. During the digestion of the contaminated meat, the initial carbonyl content of $22.6 \pm 5.0 \mathrm{nmol} / \mathrm{mg}$ protein remained stable $(22.9 \pm 0.6 \mathrm{nmol} / \mathrm{mg}$ protein) until the end of gastric digestion $\mathrm{t} 120 / \mathrm{pH} 2$ and increased to $32.9 \pm 2.3 \mathrm{nmol} / \mathrm{mg}$ proteins for $\mathrm{t} 240 / \mathrm{pH}$. The factorial ANOVA analysis showed a significant effect of $E$. coli O157:H7 CM454 inoculation on the carbonyl content $(p=0.001)$.

Lipid oxidation was determined by the measure of TBARS. The TBARS content in meat was $2.7 \mathrm{nmol}$ of MDA eq/mL at the beginning of digestion and increased up to $5.2 \mathrm{nmol}$ of MDA eq/mL at the end of digestion (Figure 1). In E. coli O157:H7 CM454contaminated meat, lipid oxidation increased by 2.8 -fold with a final content at $7.1 \mathrm{nmol}$ of MDA eq/mL. The factorial ANOVA analysis showed a significant effect of E. coli O157:H7 CM454-inoculation on lipid oxidation $(p=0.005)$. 


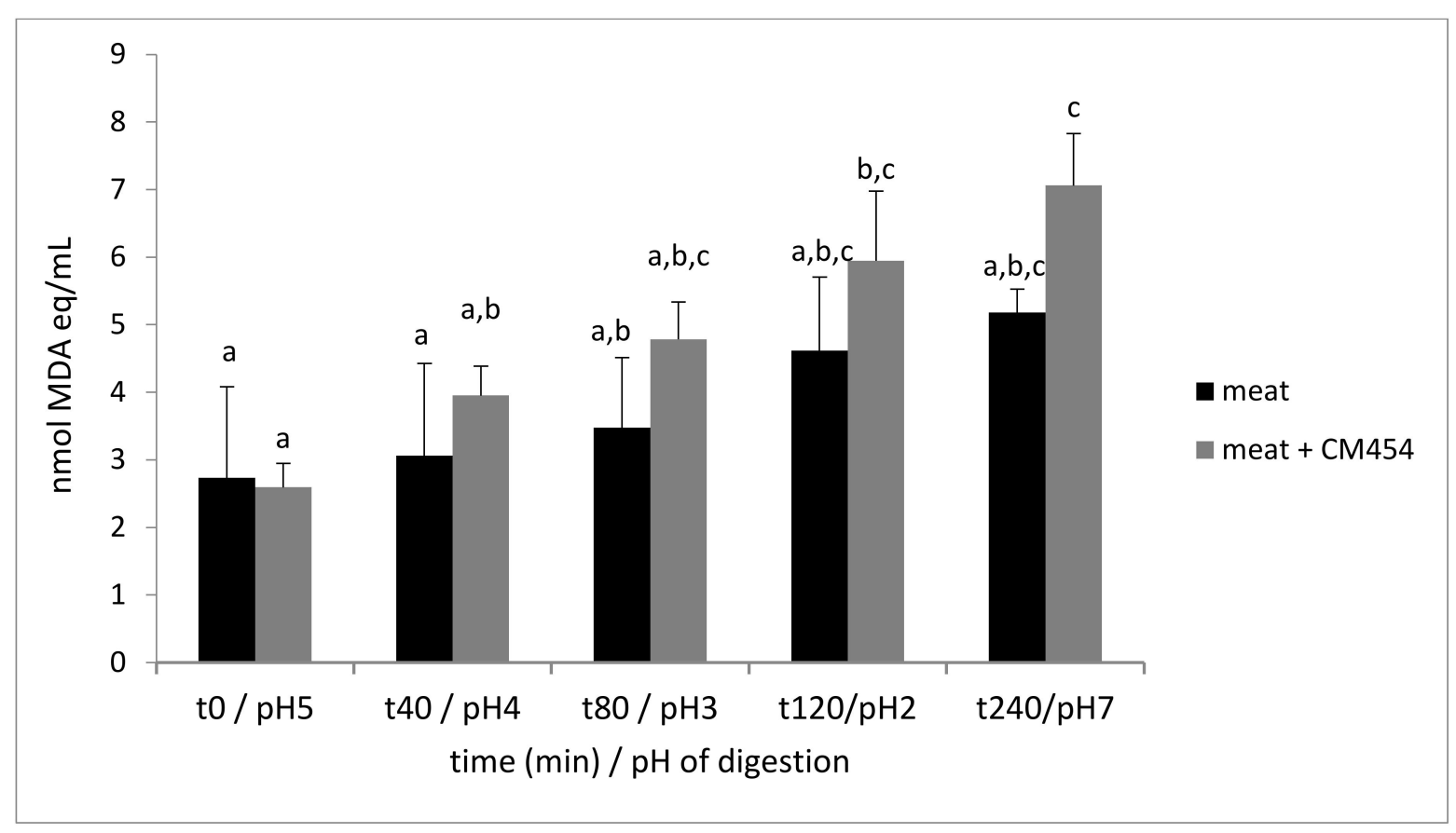

Figure 1. Lipid oxidation during digestion of meat inoculated or not with E. coli O157:H7 CM454. Values are mean $+/-$ standard deviation of 3 independent biological replicates. Different letters indicate significantly different values $(p<0.05)$ by factorial ANOVA.

\subsubsection{E. coli O157:H7 CM454 Did Not Impact Nitrosylation}

The heme iron content was $46.1 \pm 2.5 \mu \mathrm{M}$ during meat digestion and $45.5 \pm 3.0 \mu \mathrm{M}$ during the digestion of contaminated meat. These values were similar and remained stable throughout digestion. The percentage of nitrosylation increased in the gastric compartment both in the noninoculated and inoculated meat (Figure 2). Maximal values were obtained at the end of gastric digestion, with $73.1 \%$ of nitrosylation for meat and $80.4 \%$ for meat with E. coli O157:H7 CM454. For these two digestions, a fall in the nitrosylation percentage was observed in the intestinal compartment, reaching $51.9 \%$ and $43.3 \%$ of nitrosylation for the noninoculated and inoculated meat, respectively. The factorial ANOVA analysis showed no effect of E. coli O157:H7 CM454 ( $p=0.078)$ and only an effect of digestion $(p<0.001)$ on nitrosylation.

\subsubsection{E. coli O157:H7 CM454 Increased Free Iron Release and Modified Its Oxidation State}

Free iron content was assessed throughout digestion (Table 2). The release of free iron was observed during the digestion of the noninoculated and inoculated meat. The time $\mathrm{t} 80 / \mathrm{pH} 3$ seemed to be a pivotal point in our experiment. Free iron content had increased, reaching $6.6 \pm 1.2 \mu \mathrm{M}$ in the noninoculated meat and $7.5 \pm 0.8 \mu \mathrm{M}$ in the inoculated meat. Although this value remained stable until the end of digestion in the meat, it increased up to $15.3 \pm 2.4 \mu \mathrm{M}$ at the end of digestion, eightfold the initial rate in the presence of E. coli O157:H7 CM454. The factorial ANOVA analysis highlighted a significant effect of E. coli O157:H7 CM454 ( $p<0.001)$, digestion $(p<0.001)$, and the interaction between these two factors $(p<0.001)$. 
Table 2. Evolution of free iron content and $\mathrm{Fe}^{2+} / \mathrm{Fe}^{3+}$ forms during digestion of meat inoculated or not with E. coli O157:H7 CM454. Values are mean $+/-$ standard deviation of 3 independent biological replicates. Different letters indicate significantly different values, at least $p<0.05$, by factorial ANOVA.

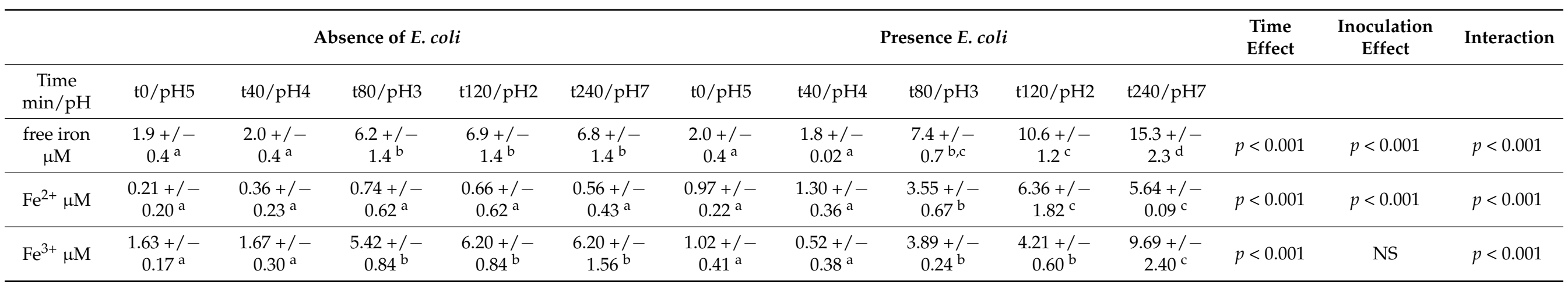




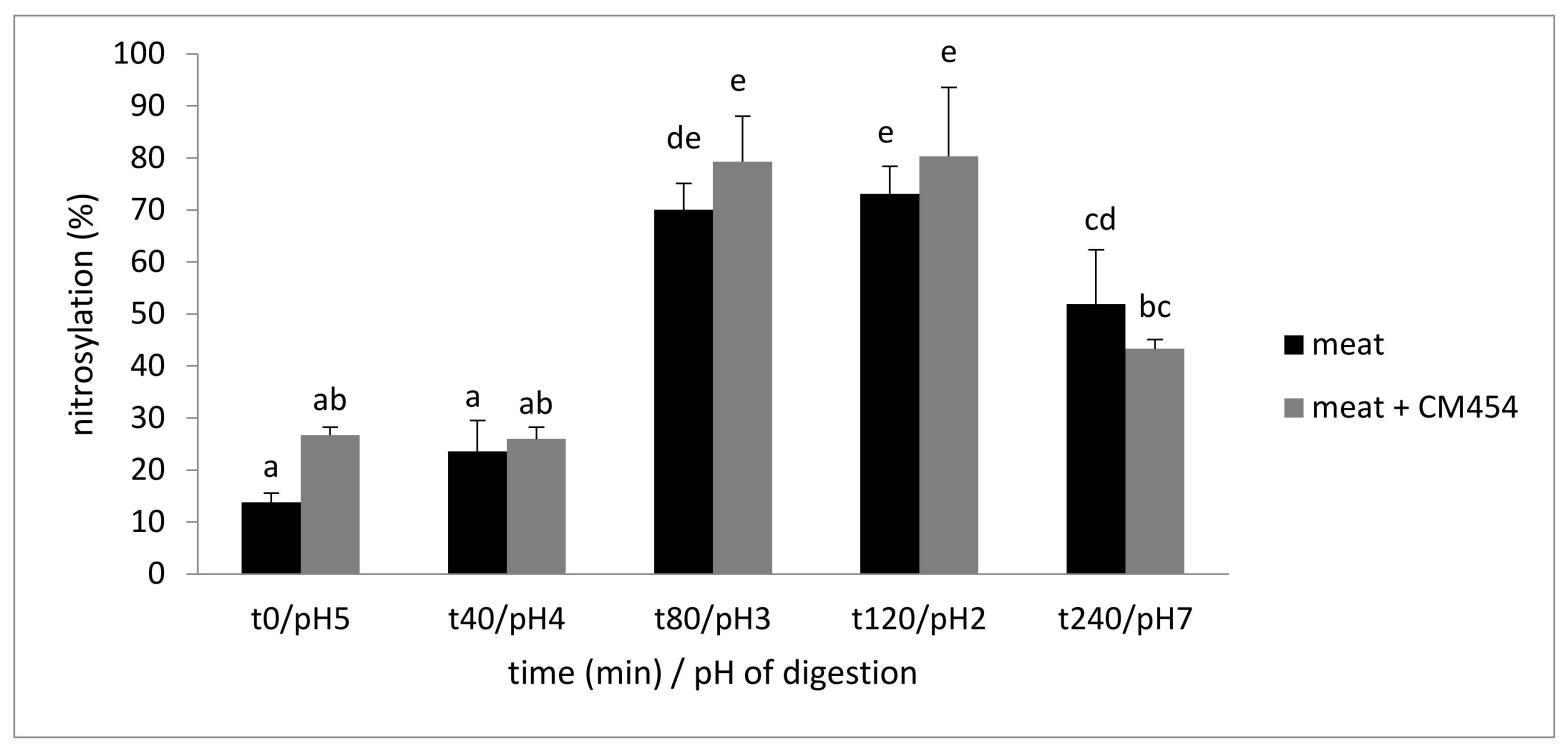

Figure 2. Evolution of the percentage of heminic iron nitrosylation during digestion of meat inoculated or not with $E$. coli O157:H7 CM454. Values are mean +/ - standard deviation of 3 independent biological replicates. Different letters indicate significantly different values $(p<0.05)$.

The $\mathrm{Fe}^{2+} / \mathrm{Fe}^{3+}$ molar ratios are shown in Table 2. During meat digestion, $89 \%$ of free iron was oxidized $\mathrm{Fe}^{3+}$ and $11 \%$ was reduced $\mathrm{Fe}^{2+}$, whereas during the digestion of contaminated meat, $47 \%$ of free iron was oxidized $\mathrm{Fe}^{3+}$ and $53 \%$ was reduced $\mathrm{Fe}^{2+}$. When the results were expressed in quantity, $\mathrm{Fe}^{3+}$ content was the same whatever the digestions of meat or contaminated meat up to the end of gastric digestion, but it was significantly different at the end of intestinal digestion (Table 2). E. coli O157:H7 CM454 inoculation led to an increase in free iron, with an $\mathrm{Fe}^{2+}$ content of $42 \%$. The factorial ANOVA analysis highlighted a significant effect of E. coli O157:H7 CM454 $(p<0.001)$, digestion $(p<0.001)$ and the interaction between these two factors $(p<0.001)$.

3.2. E. coli O157:H7 CM454 Survival and Its Interaction with Meal Components (Meat, Nitrite, and Ascorbate) throughout Digestion

\subsubsection{E. coli O157:H7 CM454 Survival Was Decreased by Nitrite/Ascorbate}

The meat was inoculated at $9.3 \pm 0.5 \mathrm{log} \mathrm{CFU} / \mathrm{g}$ by the strain E. coli O157:H7 CM454, and after storage for 3 days at $4{ }^{\circ} \mathrm{C}$ and $30 \mathrm{~min}$ at $20^{\circ} \mathrm{C}$ to reach $12{ }^{\circ} \mathrm{C}$, the enumeration was $8.4 \pm 0.6 \log \mathrm{CFU} / \mathrm{g}$. The strain was enumerated at $\mathrm{t} 0 / \mathrm{pH} 5$ in the gastric compartment, revealing $8.6 \pm 0.3 \log \mathrm{CFU} / \mathrm{mL}$ gastric fluid (Table 3). The addition of nitrite and ascorbate in the meal resulted in a decrease of $3.5 \log$ of the population throughout digestion, with a larger decrease $(2.5 \mathrm{log})$ in the gastric compartment (Table 3$)$.

Table 3. Survival of E. coli O157:H7 CM454 along the meal digestion in presence of nitrite/ascorbate. Values are mean \pm standard deviation of 3 independent biological replicates. Different letters indicate significantly different values $(p<0.05)$.

\begin{tabular}{|c|c|c|c|c|c|}
\hline $\begin{array}{c}\text { Time } \\
\mathrm{min} / \mathrm{pH}\end{array}$ & t0/pH5 & $\mathrm{t} 40 / \mathrm{pH} 4$ & t80/pH3 & t120/pH2 & $\mathrm{t} 240 / \mathrm{pH} 7$ \\
\hline $\log \mathrm{CFU} / \mathrm{mL}$ & $8.6 \pm 0.3^{a}$ & $7.7 \pm 0.5^{\mathrm{a}, \mathrm{b}}$ & $6.4 \pm 0.4^{b}$ & $6.0 \pm 0.5^{b, c}$ & $5.0 \pm 0.5^{\mathrm{c}}$ \\
\hline
\end{tabular}

In the presence of nitrite, $0.3 \%$ of the initial bacterial population was still alive at the end of gastric digestion and $0.04 \%$ at the end of intestinal digestion. 


\subsubsection{E. coli $\mathrm{O} 157: \mathrm{H7} \mathrm{CM} 454$ Impacted Nitrite and Ascorbate Chemistry}

Nitrite was added at a concentration of $1 \mathrm{mM}$ and only $2 / 3$ was recovered at $\mathrm{t} 0 / \mathrm{pH} 5$. From the start of digestion, part of the nitrite $\left(\mathrm{NO}_{2}\right)$ was oxidized into nitrate $\left(\mathrm{NO}_{3}\right)$ in both the inoculated and noninoculated samples (Table 4). However, the ratio was $63 \%$ $\mathrm{NO}_{2} / 3 \% \mathrm{NO}_{3}$ in the noninoculated meal and $81 \% \mathrm{NO}_{2} / 19 \% \mathrm{NO}_{3}$ in the inoculated meat. The nitrite rate decreased through time in the two digestions, up to time $\mathrm{t} 80 / \mathrm{pH} 3$, and then remained stable. The factorial ANOVA analysis highlighted a significant effect of $E$. coli O157:H7 CM454 $(p<0.001)$, digestion $(p<0.001)$, and the interaction of these two factors $(p=0.011)$. The nitrate level decreased during the digestion in the meal sample $(p=0.036)$ but remained stable in the inoculated meal $(p=0.907)$.

Ascorbate $1 \mathrm{mM}$ was added to the samples and recovered at the beginning of digestion (Table 4). The ascorbate content decreased similarly during the meal digestion with or without E. coli O157:H7 CM454. The factorial ANOVA analysis highlighted no effect of E. coli O157:H7 CM454 $(p=0.67)$, a significant effect of digestion $(p<0.001)$, and the interaction of these two factors $(p=0.026)$. Reduced/oxidized forms of ascorbate were also assessed. In the case of the meal digestion, $55 \%$ of the ascorbate was in the oxidized form dehydroascorbate (DHA) at the first time point $\mathrm{t} 0 / \mathrm{pH} 5$, while at the third sampling time $\mathrm{t} 80 / \mathrm{pH} 3$, a mean of $94 \%$ of ascorbate was oxidized up to the end of digestion. Conversely, during the digestion of the meal contaminated with E. coli O157:H7 CM454, 96\% of the ascorbate was in the DHA form since the beginning of digestion and $4 \%$ was in the ascorbate form. The factorial ANOVA analysis highlighted a significant effect of E. coli O157:H7 CM454 $(p<0.001)$, digestion $(p<0.001)$, and the interaction of these factors $(p<0.001)$.

\subsubsection{E. coli O157:H7 CM454 Impacted Free Iron Release and Its Oxidation State}

The free iron content was assessed throughout digestion (Table 4). It remained stable during the meal digestion, whereas the free iron content increased continuously during the digestion of the contaminated meal, from an initial value of $2.0 \pm 0.4 \mu \mathrm{M}$ to reach $12.6 \pm 2.6 \mu \mathrm{M}$ at the end of digestion, i.e., a sixfold increase. The factorial ANOVA analysis highlighted a significant effect of E. coli O157:H7 CM454 $(p<0.001)$, digestion $(p<0.001)$, and the interaction of these two factors $(p=0.002)$.

The $\mathrm{Fe}^{2+} / \mathrm{Fe}^{3+}$ forms were also determined (Table 4). At the beginning ( $\left.\mathrm{t} 0 / \mathrm{pH} 5\right)$ of digestion, approximately $20 \%$ of free iron was oxidized $\mathrm{Fe}^{3+}$ and $80 \%$ was reduced $\mathrm{Fe}^{2+}$. However, from the second time point $\mathrm{t} 40 / \mathrm{pH} 4$, the ratio changed and $75 \%$ of free iron was oxidized $\mathrm{Fe}^{3+}$ in the meal, while the initial ratio remained unchanged throughout the digestion of the meal with E. coli O157:H7 CM454. The comparison of the meal digestions with or without E. coli O157:H7 CM454 highlighted an increase in $\mathrm{Fe}^{2+}$ release of $45 \%$ in the inoculated samples $(p<0.001)$.

\subsubsection{E. coli O157:H7 CM454 Did Not Impact Protein Digestion or Lipid and Protein Oxidation}

Similar initial peptide contents at $\mathrm{t} 0 / \mathrm{pH} 5$ of $15.5 \pm 1.3$ and $15.9 \pm 3.9 \mathrm{mM}$ eq glycine were determined for both meal digestions, noninoculated or inoculated, respectively. No significant peptide release was noticed during gastric digestion in the absence of $E$. coli O157:H7 CM454. At t120/pH2, $15.2 \pm 5.0$ and $32.2 \pm 9.2 \mathrm{mM}$ eq glycine were determined in the absence and presence of E. coli O157:H7 CM454, respectively. However, at the end of intestinal digestion point $\mathrm{t} 240 / \mathrm{pH} 7$, the peptide content was 2.9 -fold higher in the noninoculated meal and 3.5-fold in the meal with E. coli O157:H7 CM454 ( $p=0.05)$.

Protein and lipid oxidation did not change in the meal in the absence or presence of E. coli O157:H7 CM454. The content of carbonyls was $29.5 \pm 4.3 \mathrm{nmol} / \mathrm{mg}$ proteins and $20.2 \pm 6.1 \mathrm{nmol} / \mathrm{mg}$ proteins during the digestion of the meal and the inoculated meal, respectively. Similarly, lipid oxidation remained stable $(<4.0 \mathrm{nmol}$ of MDA eq/ $\mu \mathrm{L})$ throughout the meal digestion whether or not E. coli O157:H7 CM454 was present. 


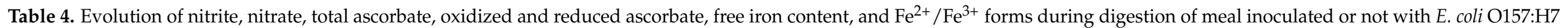

CM454. Values are mean \pm standard deviation of 3 independent biological replicates. Different letters indicate significantly different values, at least $p<0.05$, by factorial ANOVA.

\begin{tabular}{|c|c|c|c|c|c|c|c|c|c|c|c|c|c|}
\hline & & & Absence of $E . c o l$ & & & & & Presence E. col & & & $\begin{array}{l}\text { Time } \\
\text { Effect }\end{array}$ & $\begin{array}{c}\text { Inoculation } \\
\text { Effect }\end{array}$ & Interaction \\
\hline Time $\mathrm{min} / \mathrm{pH}$ & $\mathrm{t} 0 / \mathrm{pH} 5$ & $\mathrm{t} 40 / \mathrm{pH} 4$ & $\mathrm{t} 80 / \mathrm{pH} 3$ & $\mathrm{t} 120 / \mathrm{pH} 2$ & $\mathrm{t} 240 / \mathrm{pH} 7$ & $\mathrm{t} 0 / \mathrm{pH} 5$ & $\mathrm{t} 40 / \mathrm{pH} 4$ & $\mathrm{t} 80 / \mathrm{pH} 3$ & $\mathrm{t} 120 / \mathrm{pH} 2$ & $\mathrm{t} 240 / \mathrm{pH} 7$ & & & \\
\hline Nitrite & $404 \pm 28^{a}$ & $312 \pm 70 \mathrm{a}, \mathrm{b}$ & $236 \pm 43^{b}$ & $269 \pm 71^{a, b}$ & $263 \pm 68^{a, b}$ & $580 \pm 58^{c}$ & $591 \pm 64^{c}$ & $354 \pm 35^{a, b}$ & $359 \pm 40 \mathrm{a}, \mathrm{b}$ & $296 \pm 47^{a, b}$ & $p<0.001$ & $p<0.001$ & $p<0.001$ \\
\hline Nitrate & $241 \pm 34^{\mathrm{a}}$ & $258 \pm 30^{\mathrm{a}}$ & $142 \pm 23^{a, b}$ & $96 \pm 52^{b}$ & $82 \pm 56^{\mathrm{b}}$ & $139 \pm 30^{a, b}$ & $179 \pm 80^{a, b}$ & $182 \pm 41^{a, b}$ & $187 \pm 86^{\mathrm{a}, \mathrm{b}}$ & $145 \pm 76^{a, b}$ & $p<0.001$ & NS & $p<0.001$ \\
\hline Total ascorbate & $0.15 \pm 0.06^{\mathrm{a}}$ & $1.06 \pm 0.06^{\mathrm{a}}$ & $1.06 \pm 0.03^{\mathrm{a}}$ & $1.06 \pm 0.05^{\mathrm{a}}$ & $0.54 \pm 0.21^{c}$ & $1.26 \pm 0.12^{\mathrm{a}}$ & $1.04 \pm 0.08^{\mathrm{a}}$ & $0.96 \pm 0.15^{a, b}$ & $0.69 \pm 0.17^{b, c}$ & $0.52 \pm 0.02^{c}$ & $p<0.001$ & NS & $p<0.001$ \\
\hline Oxidized ascorbate & $0.63 \pm 0.08^{a, b}$ & $0.61 \pm 0.07^{a, b}$ & $0.99 \pm 0.18^{\mathrm{b}}$ & $1.02 \pm 0.10^{\mathrm{b}}$ & $0.49 \pm 0.22^{c}$ & $1.28 \pm 0.08^{\mathrm{b}}$ & $0.99 \pm 0.12^{b}$ & $1.09 \pm 0.29^{b}$ & $0.66 \pm 0.14^{c}$ & $0.54 \pm 0.12^{\mathrm{c}}$ & $p<0.001$ & $p<0.001$ & $p<0.001$ \\
\hline Reduced ascorbate & $0.51 \pm 0.13^{\mathrm{a}}$ & $0.44 \pm 0.05^{\mathrm{a}}$ & $0.08 \pm 0.13^{\mathrm{b}}$ & $0.06 \pm 0.10^{\mathrm{b}}$ & $0.04 \pm 0.02^{b}$ & $0.006 \pm 0.01^{\mathrm{b}}$ & $0.05 \pm 0.05^{\mathrm{b}}$ & $0.006 \pm 0.01^{b}$ & $0.033 \pm 0.033^{b}$ & $0.034 \pm 0.039^{b}$ & $p<0.001$ & $p<0.001$ & $p<0.001$ \\
\hline free iron $\mu \mathrm{M}$ & $2.26 \pm 0.36^{a, b}$ & $2.29 \pm 0.24 \mathrm{a}, \mathrm{b}$ & $3.77 \pm 0.44^{\mathrm{a}, \mathrm{c}}$ & $4.39 \pm 0.31^{\mathrm{a}, \mathrm{c}}$ & $3.94 \pm 0.40^{\mathrm{a}, \mathrm{c}}$ & $2.01 \pm 0.39^{\mathrm{a}}$ & $6.70 \pm 0.82^{b, c}$ & $7.67 \pm 2.26^{\mathrm{c}}$ & $11.28 \pm 3.60^{c, d}$ & $12.56 \pm 2.51 \mathrm{~d}, \mathrm{e}$ & $p<0.001$ & $p<0.001$ & $p<0.001$ \\
\hline $\mathrm{Fe}^{2+} \mu \mathrm{M}$ & $1.79 \pm 0.29^{\mathrm{a}}$ & $0.66 \pm 0.39^{\mathrm{a}}$ & $1.73 \pm 1.16^{a, b}$ & $0.71 \pm 0.62^{\mathrm{a}}$ & $0.35 \pm 0.38^{a}$ & $2.12 \pm 0.48^{a, b}$ & $6.06 \pm 1.10^{\mathrm{b}}$ & $5.71 \pm 3.32^{b}$ & $9.38 \pm 3.80^{b, c}$ & $10.02 \pm 0.61^{b, c}$ & $p<0.001$ & $p<0.001$ & $p<0.001$ \\
\hline $\mathrm{Fe}^{3+} \mu \mathrm{M}$ & $0.48 \pm 0.46^{\mathrm{a}}$ & $1.63 \pm 0.56^{a, b}$ & $2.04 \pm 0.94 \mathrm{a}, \mathrm{b}$ & $3.67 \pm 0.37^{b}$ & $3.59 \pm 0.35^{b}$ & $0.38 \pm 0.19^{\mathrm{a}}$ & $0.58 \pm 0.33^{\mathrm{a}}$ & $1.55 \pm 1.42^{\mathrm{a}, \mathrm{b}}$ & $1.96 \pm 0.95^{a, b}$ & $2.09 \pm 2.21 \mathrm{a}, \mathrm{b}$ & $p<0.001$ & $p<0.001$ & NS \\
\hline
\end{tabular}




\subsubsection{E. coli O157:H7 Impacted Nitrosylation}

Heme iron concentration was stable throughout both digestions: $52.5 \pm 1.2 \mu \mathrm{M}$ at the beginning and $50.9 \pm 3.4 \mu \mathrm{M}$ at the end of the meal digestion; and $57.1 \pm 5.6 \mu \mathrm{M}$ and $58.1 \pm 4.2 \mu \mathrm{M}$ in the presence of $E$. coli O157:H7 CM454. No effect of E. coli O157:H7 CM454 on digestion was shown.

However, the percentage of nitrosylation varied during digestion (Figure 3). It was $46.5 \%$ at the beginning of the digestion of the meal, it reached a maximum of $87.7 \%$ at $\mathrm{t} 80 / \mathrm{pH} 3$, and it remained stable up to $\mathrm{t} 120 / \mathrm{pH} 2$. In the contaminated meal, the percentage of nitrosylation began at $13.2 \%$ and rose to a maximum of $79.0 \%$ at point $t 120 / \mathrm{pH} 2$. Then, a significant decrease in iron nitrosylation of $25 \%$ was observed in this sample at the end of intestinal digestion.

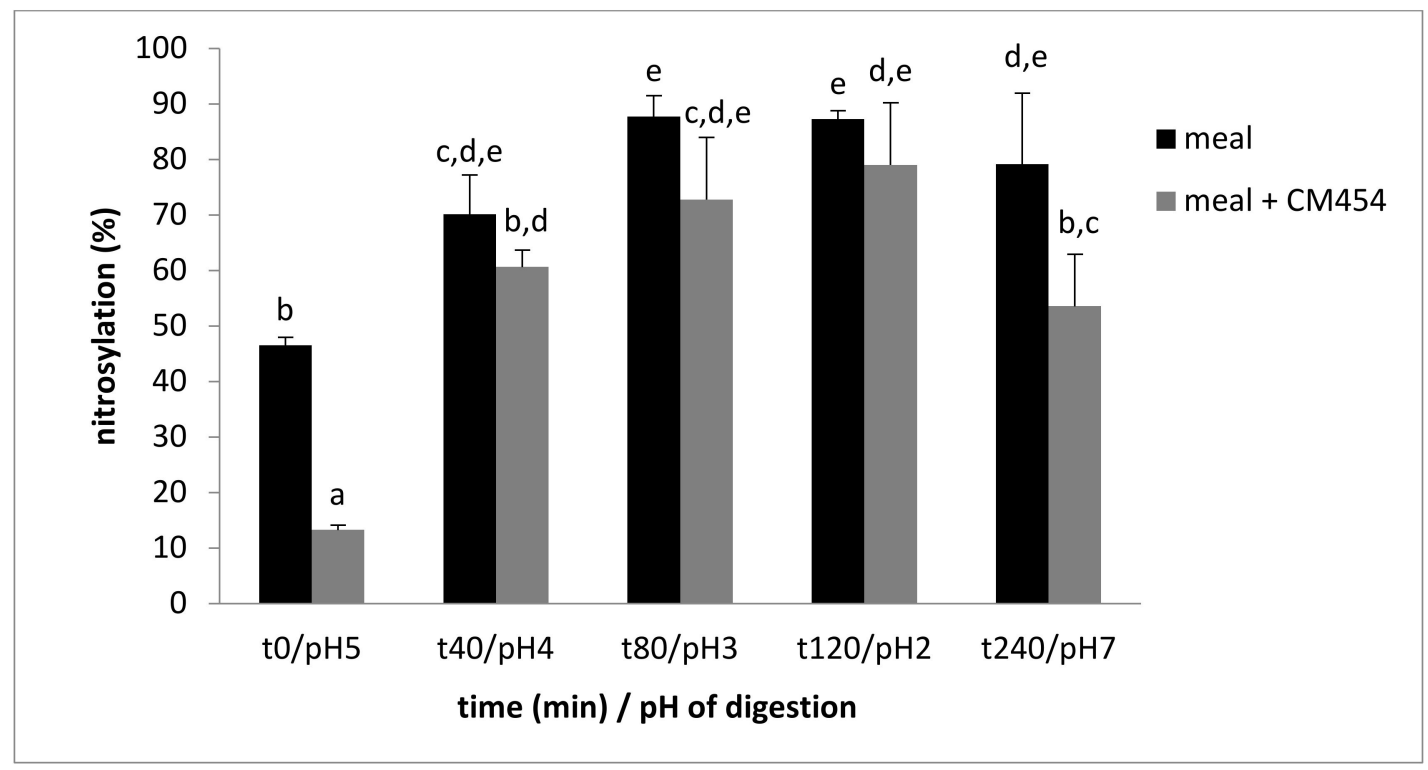

Figure 3. Evolution of the percentage of heminic iron nitrosylation during digestion of a meal (meat, nitrite, and ascorbate) noninoculated or inoculated with E. coli O157:H7 CM454. Values are mean +/ - standard deviation of 3 independent biological replicates. Different letters indicate significantly different values $(p<0.05)$ by factorial ANOVA analysis.

The factorial ANOVA analysis showed a significant effect of E. coli O157:H7 CM454 $(p<0.001)$ and digestion $(p<0.001)$ on nitrosylation.

\subsubsection{E. coli O157:H7 CM454 Did Not Impact N-Nitrosation but Impacted S-Nitrosation}

A similar amount of nitrosamines (about $220 \mu \mathrm{M}$ ) was assessed from the beginning of digestion in both meal samples. Nitrosamine content decreased continuously throughout digestion until the end of gastric digestion (content divided by 8), and nitrosamines were no longer detectable in the intestinal compartment (Figure 4). The factorial ANOVA analysis showed a significant effect of digestion $(p<0.001)$ and no effect of $E$. coli O157:H7 CM454 $(p=0.391)$.

During the meal digestion, the nitrosothiol content was relatively stable during gastric digestion with a value fluctuating from 142.5 to $187.8 \mu \mathrm{M}$ (Figure 5). Then, in the intestinal compartment, no nitrosothiol was detectable. Only traces of nitrosothiols were detected during the digestion of the contaminated meal. The factorial ANOVA analysis showed a significant effect of E. coli O157:H7 CM454 ( $p<0.001)$, digestion $(p<0.001)$, and the interaction of these two factors $(p<0.001)$. 


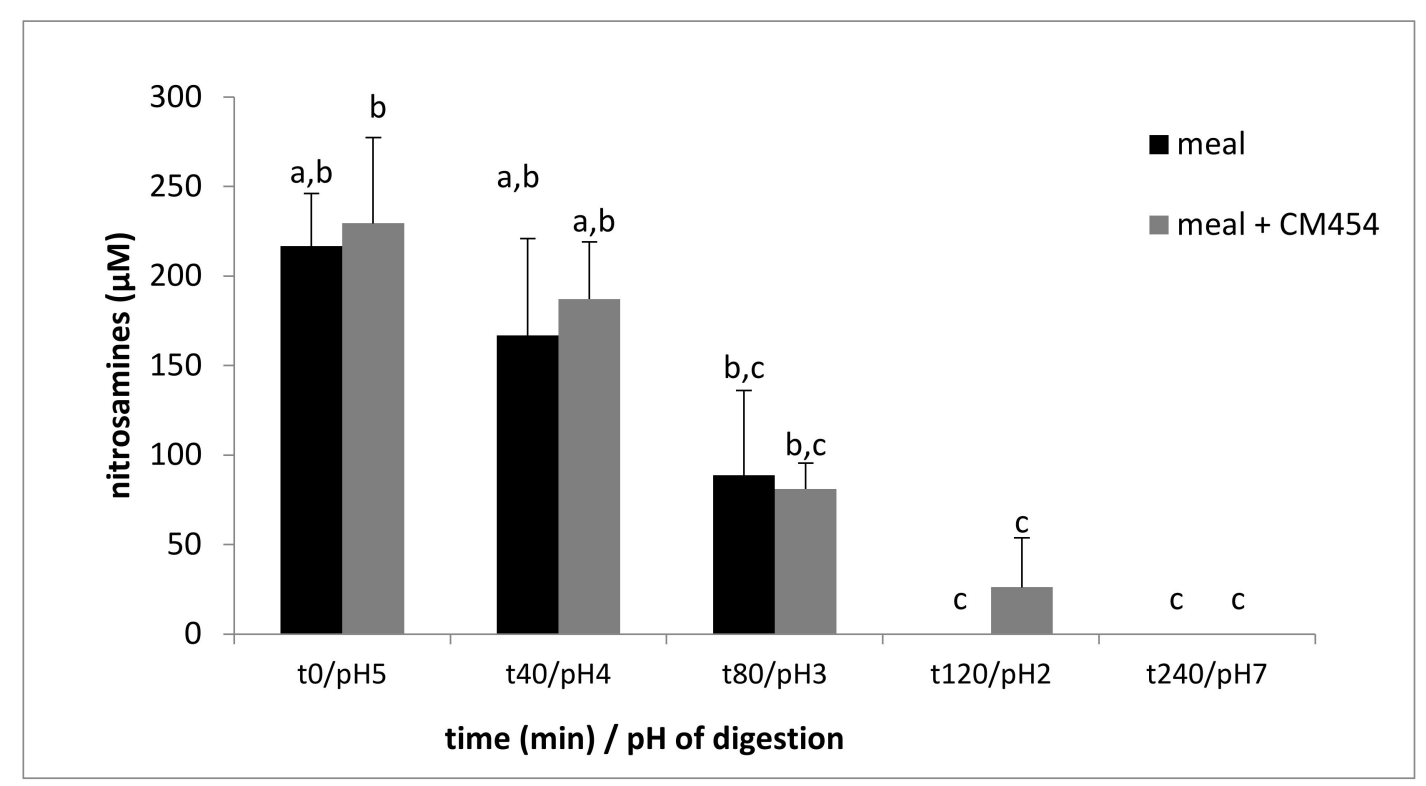

Figure 4. Evolution of nitrosamines content during digestion of a meal (meat, nitrite, and ascorbate) noninoculated or inoculated with E. coli O157:H7 CM454. Values are mean +/- standard deviation of 3 independent biological replicates. Different letters indicate significantly different values $(p<0.05)$ by factorial ANOVA.

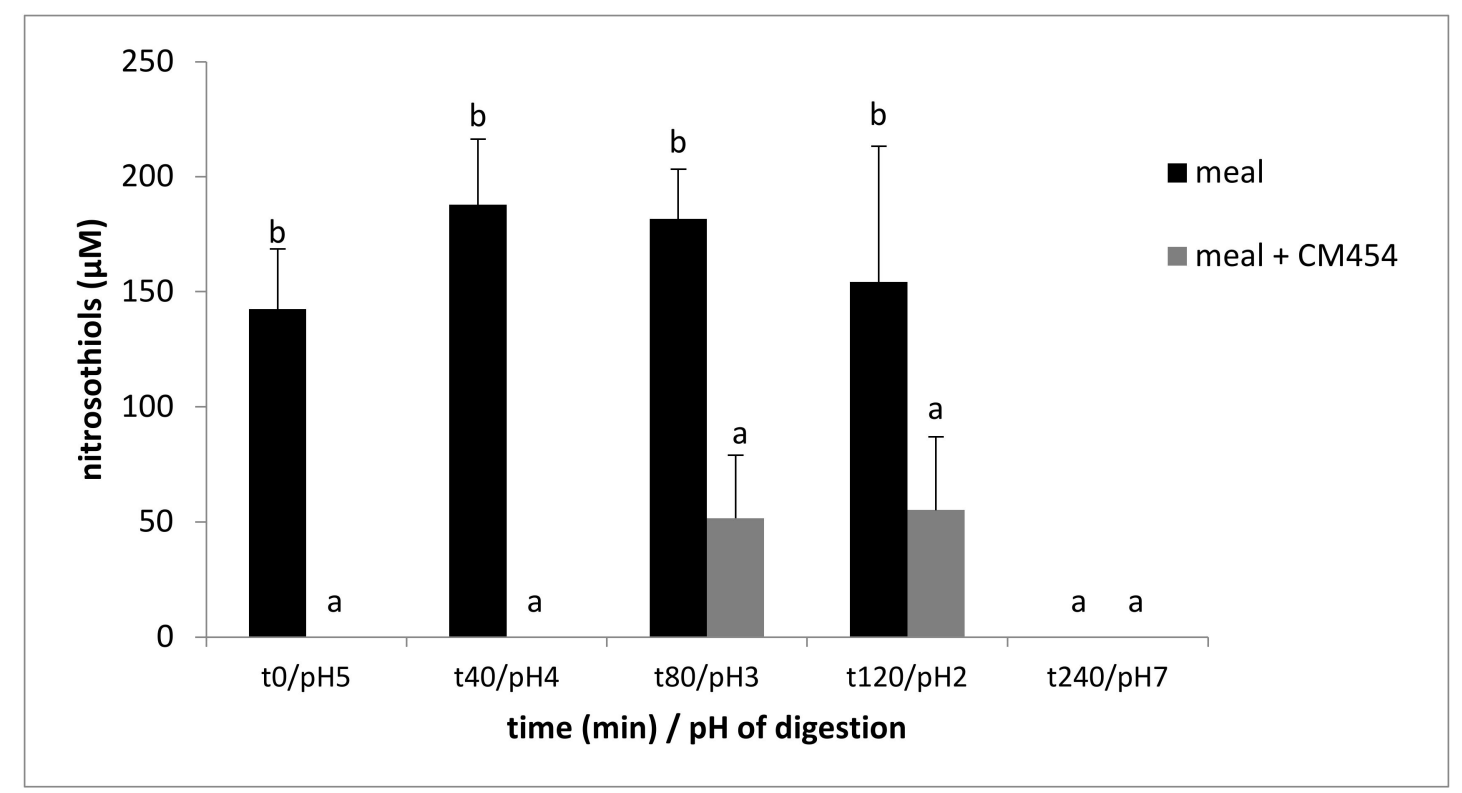

Figure 5. Evolution of nitrosothiols content during digestion of a meal (meat, nitrite, and ascorbate) noninoculated or inoculated with E. coli O157:H7 CM454. Values are mean +/ - standard deviation of 3 independent biological replicates. Different letters indicate significantly different values $(p<0.05)$ by factorial ANOVA.

\subsection{Principal Component Analysis (PCA)}

PCAs were carried out on the complete dataset at $\mathrm{t} 0$, at the end of gastric digestion $\mathrm{t} 120$, and at the end of intestinal digestion $\mathrm{t} 240$ (Figure 6). These analyses illustrated the effect of E. coli O157:H7 CM454 on the biochemical evolution of meat during digestion. 


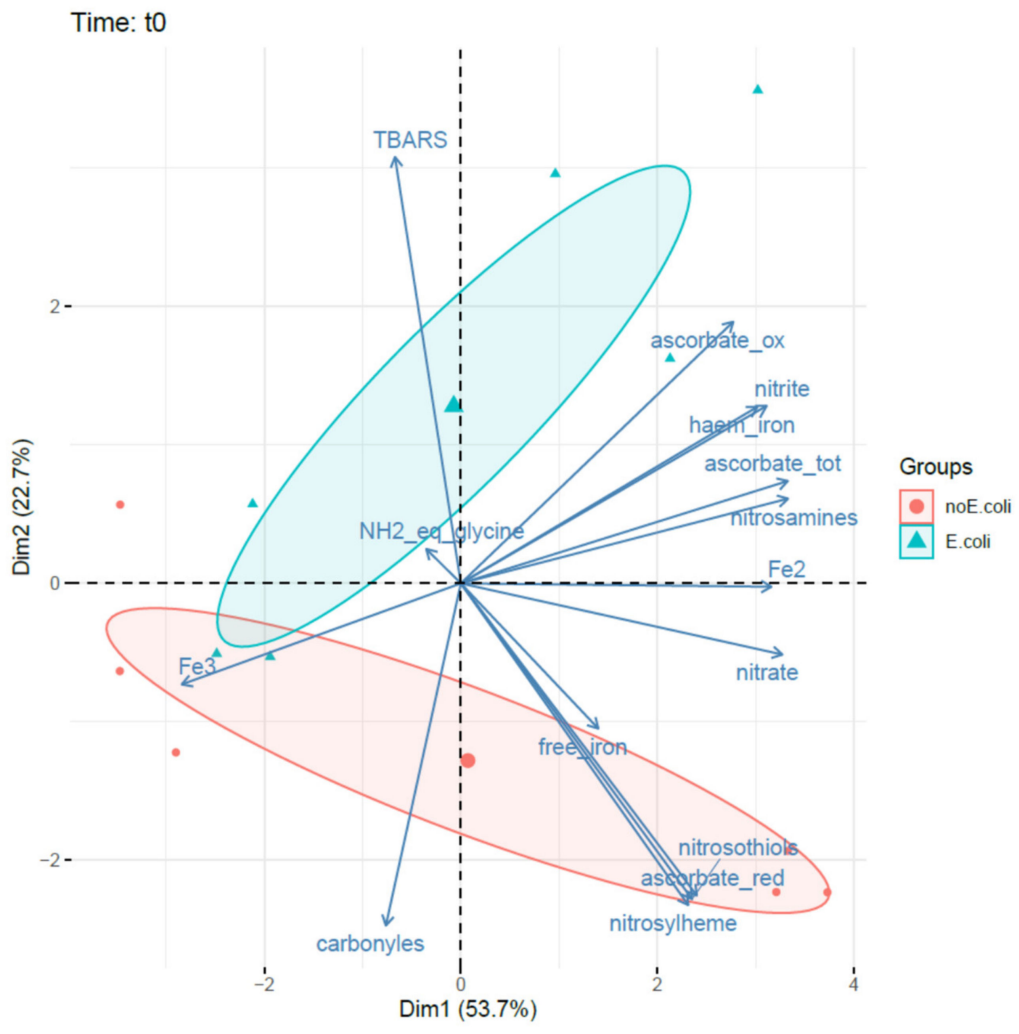

(A)

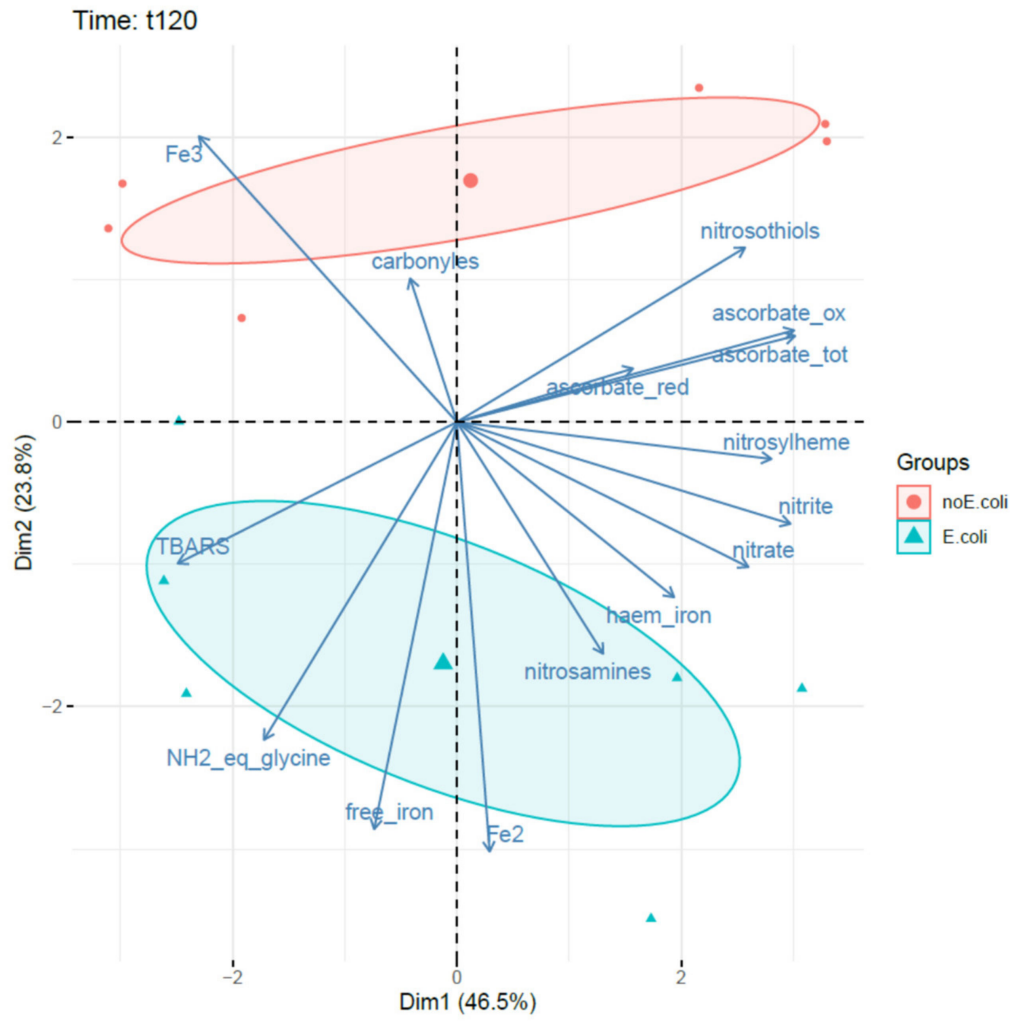

(B)

Figure 6. Cont. 


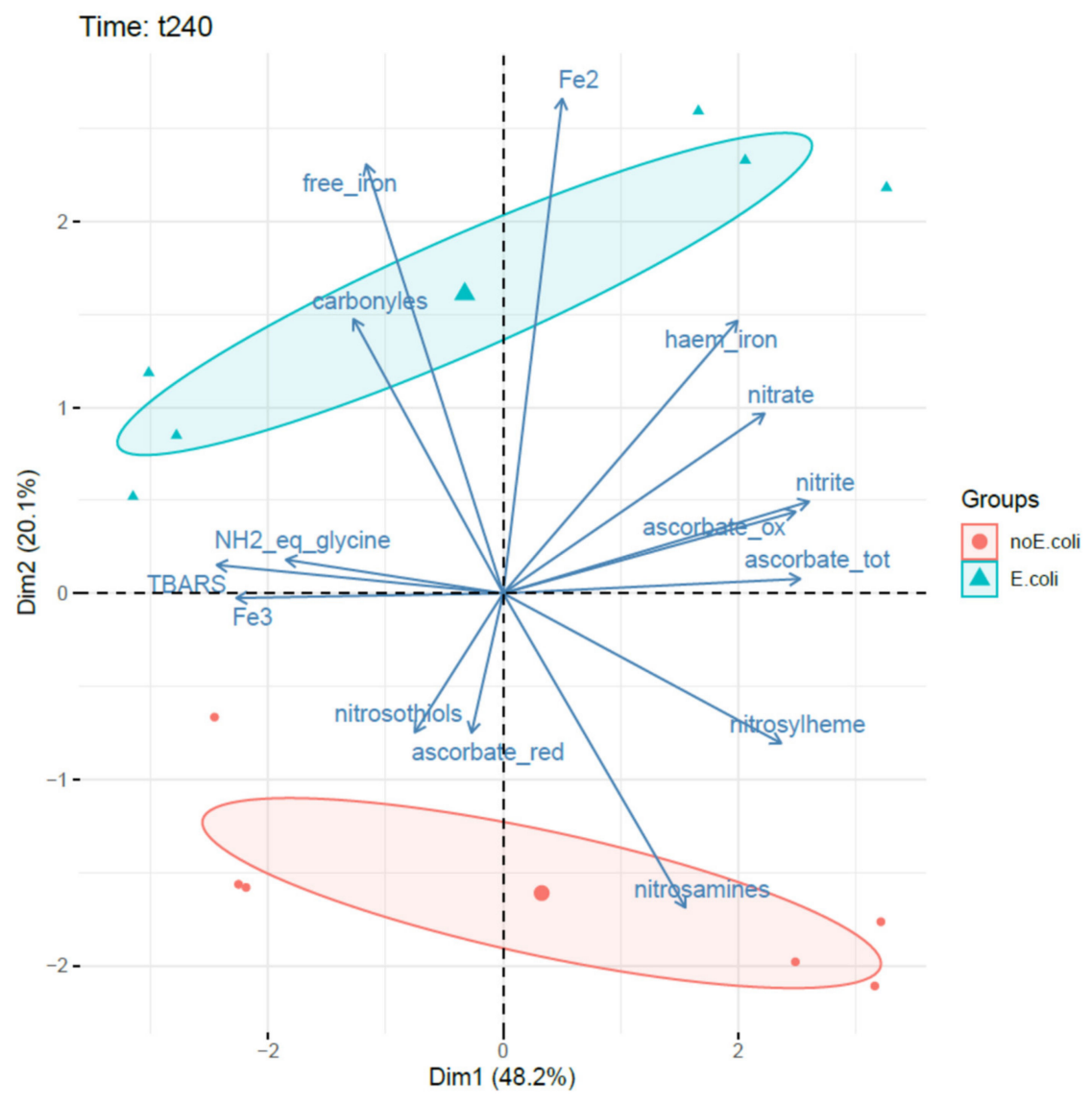

(C)

Figure 6. Effect of E. coli O157:H7 CM454 and nitrite/ascorbate on the biochemical measurements at different times of digestion. (A): PCA at $\mathrm{t} 0 / \mathrm{pH} 5$; (B): PCA at t120/pH2; (C): PCA at t240/pH7.

At $\mathrm{t} 0 / \mathrm{pH} 5,74.5 \%$ of the total variance was explained, with $53.2 \%$ for the first component and $21.3 \%$ for the second one (Figure $6 \mathrm{~A}$ ). The first axis corresponded roughly to the meal composition, and the two ellipses (E. coli/no E. coli) tended to split up.

At the end of gastric digestion, $\mathrm{t} 120 / \mathrm{pH} 2,66.5 \%$ of the total variance was explained, with $44.2 \%$ for the first component and $22.3 \%$ for the second one (Figure $6 \mathrm{~B}$ ). At the end of intestinal digestion, $\mathrm{t} 240 / \mathrm{pH} 7,68 \%$ of the total variance was explained, with $48.9 \%$ for the first component and $19.1 \%$ for the second one (Figure 6C). At $120 \mathrm{~min}$, the first axis opposed nitrite/nitrate content to lipid oxidation of meat and the second axis corresponded to inoculation. Interestingly, the variables associated with inoculated meat were the amount of free iron and its reduced form $\mathrm{Fe}^{2+}$. At the end of digestion ( $\mathrm{t} 240 \mathrm{~min}$ ), a similar projection was observed, this time oxidized free iron correlated with lipid oxidation on the first axis, while E. coli inoculation was still associated positively with free iron content.

\section{Discussion}

\subsection{Static Digestive Model of Meat}

To better understand the survival of E. coli O157:H7 CM454 during digestive conditions, the model used followed the static digestive system reported by Minekus [29] in the network of European researchers of Infogest. It is important to consider food buffering capacity during gastric digestion because it has an impact on intragastric $\mathrm{pH}$ and gastric secretion rate and possibly bacterial survival. Previous in vivo [40,41] and in vitro studies $[42,43]$ reported a high buffer capacity of meat. The semidynamic model used mimicked meat buffering capacity as the $\mathrm{pH}$ of the gastric fluid increased from 2 to 5 after 
the addition of meat; then, $\mathrm{HCl}$ was added step by step to decrease the $\mathrm{pH}$ to 2 to mimic gastric secretion.

Similarly, the same concentrations of enzymes and digestive fluids and conditions described by Minekus were adopted [29]. These concentrations mimic the digestion of children (24 months) and adults [44] and thus were relevant for the purpose of studying the survival of E. coli O157:H7 responsible for severe symptoms, particularly in children.

\subsection{Survival of E. coli O157:H7 during Digestion of Meat and Meal}

In this study, the E. coli O157:H7 CM454 strain inoculated in ground meat could survive throughout digestion despite acidic $\mathrm{pH}$. At the end of gastric digestion, $\mathrm{t} 120 / \mathrm{pH} 2,5 \%$ of the initial bacterial population was still alive. This ability to resist an acidic environment could be attributed to the presence in E. coli O157:H7 of five acid resistance systems, with four dependent on amino acid decarboxylases (arginine, glutamate, lysine, ornithine, AR2, AR3, AR4, and AR5) and another called the glucose-suppressed system (AR1) [45,46]. The glutamate system is most effective at $\mathrm{pH} 2$, while the arginine system is more efficient at pH 2.5 [46].

E. coli O157:H7 strain CM454 survived in the intestinal part when bile salts were added. Bile salts could act as an inhibitor via their detergent properties that enable the disruption of bacterial membranes [47-49] and via their action as DNA-damaging agents [20,49]. E. coli $\mathrm{O} 157$ has developed mechanisms of resistance to bile, including modified membrane structures that reduce bile permeability $[7,48,49]$ and the active removal of bile acids due to efflux pumps $[7,47,48,50,51]$.

The addition of nitrite and ascorbate, here mimicking the contribution of vegetables in the digestion medium, resulted in a drastic reduction in the E. coli O157:H7 CM454 population both at the end of gastric digestion ( $0.30 \%$ of the initial population) and of intestinal digestion ( $0.04 \%$ of the initial population). Compared to meat digestion, bacterial survival was reduced 5-fold in the gastric compartment and 51-fold in the intestinal one. The inhibitory property of nitrite could be attributed to the nitrosative stress generated [7,52]. The physicochemical conditions of the stomach such as oxygen pressure, low $\mathrm{pH}$, and reducing conditions favor the formation of nitrite derivatives such as nitric oxide (NO). A synergetic effect of $\mathrm{NO}$ and acid $\mathrm{pH}$ has been observed on the reduction in survival of an E. coli O157 strain [53]. NO can react with DNA, proteins, and lipids, thereby resulting in antimicrobial activity [7,52]. E. coli O157:H7 possesses several resistance mechanisms against $\mathrm{NO}$ that could explain its survival. Up to now, four NO detoxification pathways have been characterized: flavohemoglobin HmpA [53], flavorubredoxin NorV [54,55], hybrid cluster protein Hcp-Hcr, and nitrite reductases NrfA and NirB [56,57].

\subsection{E. coli O157:H7 CM454 Increased the Release of Iron}

Free iron was released during meat and meal digestions. This release of free iron could be due to the acidification in the stomach and to the continuous proteolytic degradation of the iron-containing proteins, as has already been shown during the digestion of raw meat with or without nitrite [16]. The possible source of free iron could be either heme iron or storage proteins such as ferritin. Under our condition, the fact that the level of heme iron remained stable during digestion whatever the condition suggested a release of free iron from ferritin. Hoppler et al., (2007) reported the release of iron from pea ferritin under digestive conditions due to acid-induced structural alterations and the dissociation of proteins [56]. Interestingly, iron release was increased in the presence of E. coli O157:H7 CM454 in both digestions: 2.6-fold in meat and 4-fold in the meal at the end of the digestion. Iron is an essential micronutrient for bacteria, but it had to be closely regulated as overaccumulation results in an oxidative burden that could lead to cell death. To maintain iron homeostasis, E. coli has developed several mechanisms such as siderophores, citrate, and low-molecular-weight thiols such as ligands and iron storage proteins belonging to the ferritin family [57]. We can assume that E. coli O157:H7 CM454 grown in meat, an iron-rich 
medium, may have stored it and then released it during the lysis of many bacteria during digestion.

Finally, whether meat or meal digestion, the presence of E. coli O157:H7 CM454 modified the percentage of ferrous ion, which meant a more reducing medium, possibly due to oxygen consumption by the bacteria [58]. It could also be attributed to the role of ascorbate as an electron donor, as, in the presence of E. coli O157:H7 CM454, ascorbate was oxidized (DHA).

\subsection{E. coli O157:H7 CM454 Impacted the Formation of Nitroso Compounds}

The heme iron was nitrosylated during digestion, with a different range according to digestion $\mathrm{pH}$. Clearly, acidic $\mathrm{pH}$ enhanced the nitrosylation of myoglobin even in the absence of added nitrite. Meat contains residual nitrate possibly reduced to nitrite, as reported by Honickel (2008), possibly forming $\bullet \mathrm{NO}$ [59]. A recent study demonstrated the formation of nitrosylheme in a cooked ham model manufactured without sodium nitrite [60]. During digestion, increased myoglobin nitrosylation can be explained by the acidic and reducing conditions of the stomach that favors the formation of nitrous acid $(\mathrm{HNO} 2)$ first, then nitric oxide $(\bullet \mathrm{NO})$. The reaction of nitric oxide with myoglobin differs according to the oxidation state of myoglobin. According to de La Pomélie et al. (2018) [16], the nitrosylation of metmyoglobin is reduced by $30 \%$ compared to oxymyoglobin. This reaction is also modulated by oxygen content in the medium. Interestingly, E. coli O157:H7 CM454 reduced myoglobin nitrosylation, particularly at the beginning and the end of the meal digestion. As $\bullet \mathrm{NO}$ is involved in nitrosylation, E. coli O157:H7 could trigger its detoxification systems, as mentioned above, and thus reduce nitrosylation.

During meal digestion, nitrosothiols were formed only in the gastric compartment. The nitrosating agent involved in nitrosothiol formation is also nitric oxide (NO•) [61] The level of nitrosothiols was very low in the presence of E. coli O157:H7 CM454. This result could be related to the systems of detoxification of $\mathrm{NO} \bullet$, as already mentioned above. Moreover, this near-absence of nitrosothiols could be explained by the utilization of sulfur compounds such as cysteine or cysteine-containing peptide glutathione by E. coli [62]. It was reported that the decomposition rate of nitrosated glutathione is higher near physiological $\mathrm{pH}$, in the presence of divalent ions such as $\mathrm{Cu} 2+$. These results could explain the nondetection of nitrosothiols in the intestinal compartment [63].

Nonvolatile nitrosamines were assayed at the beginning of the meal digestion, and then their amount decreased in the gastric compartment and no nitrosamines were detected at the end of digestion. This decrease has already been shown; it resulted in their degradation into several products not measured under our conditions [64]. In acidic medium, nitrous acid ( $\mathrm{HNO} 2)$ led to the formation of a nitrosonium cation (NO+), which is the nitrosating agent in N-nitrosation [65]. E. coli O157:H7 CM454 did not affect the formation of nitrosamines. This led us to assume that it did not interact with the nitrosonium cation. In a very different field, i.e., wastewater treatment, the fate of nitrosamines from sludge digestion was associated with their possible role as electron acceptors. In the case of NDMA (N-nitrosodimethylamine), it was shown nitrosamines can be used as an electron acceptor and reduced to ammonia and DMA (dimethylamine), in other words, the reduction of the nitroso group and subsequent N-N cleavage, explaining the loss of nitrosamines [66].

\subsection{Oxidative Processes during Digestion}

Lipid oxidation was recorded only during meat digestion. The addition of nitrite/ ascorbate to the meat led to a stable level of oxidation whether or not in presence of bacterial contamination. In the products, the antioxidant effect of nitrite has been well documented in cured meat [65], and the action of nitrite against lipid oxidation during gastrointestinal digestion is based on the reaction of nitric oxide with superoxide radicals and lipid radicals to form stable LONO and unstable LOONO that decompose into stable LONO2 (NO• + $\mathrm{L}(\mathrm{O}) \mathrm{O} \bullet \rightarrow \mathrm{L}(\mathrm{O}) \mathrm{ONO})$, hence ending the oxidation process [23]. 
Contrary to the increase in lipid oxidation reported for meat digestion and enhanced by the presence of E. coli O157:H7 CM454, our results agree with those reported during the gastrointestinal digestion of beef meat carried out in vivo using cannulated pigs. The increase in lipid oxidation during beef digestion was lowered in the presence of antioxidant/polyphenols obtained from fruits and vegetables [66].

\section{Conclusions}

The E. coli O157:H7 CM454 strain inoculated in ground meat could survive throughout digestion, certainly due to its acid and bile resistance mechanisms. The addition of nitrite and ascorbate resulted in a drastic reduction in the E. coli O157:H7 CM454 population. Nitrite can lead to the formation of nitroso compounds such as NO responsible for nitrosative stress that affects the survival of the strain. However, E. coli O157:H7 possesses several NO detoxification mechanisms that could explain the reduction of nitrosothiols formed and myoglobin nitrosylation during the digestion of the meal contaminated by the strain. The formation of nitrosamines during digestion was not affected by E. coli O157:H7 CM454; this led us to suppose that it did not interact with the nitrosonium cation. Free iron was released during the digestions and this release was increased in the presence of $E$. coli O157:H7 CM454, possibly related to lysis of the strain. In order to better understand gene modulation in the digestive environment, transcriptomic analysis will be performed using RNA-sequencing.

Supplementary Materials: The following are available online at https:/ /www.mdpi.com/article/10 .3390/foods10102415/s1, Supplementary Data S1, Supplementary Data S2.

Author Contributions: Conceptualization, S.L., R.T., P.G., V.S.-L.; investigation, D.d.L.P.; writingoriginal draft preparation, D.d.L.P.; writing—review and editing, S.L., R.T., P.G., V.S.-L.; supervision, S.L., R.T., P.G., V.S.-L.; project administration, S.L., R.T., P.G., V.S.-L.; statistical analysis, P.R.; funding acquisition, P.G., R.T., S.L., V.S.-L., data curation: D.d.L.P., formal analysis: D.d.L.P. All authors have read and agreed to the published version of the manuscript.

Funding: This research was financed by the French government IDEX-ISITE initiative 16-IDEX0001(CAP 2025) and by INRAE.

Institutional Review Board Statement: Not applicable.

Informed Consent Statement: Not applicable.

Acknowledgments: Diane de La Pomelie is granted by the "Conseil régional d'Auvergne-RhôneAlpes-FEDER (Fonds Européen de Développement Régional)".

Conflicts of Interest: The authors declare no conflict of interest.

\section{References}

1. Panel, E.F.S.A.B.; Koutsoumanis, K.; Allende, A.; Alvarez-Ordóñez, A.; Bover-Cid, S.; Chemaly, M.; Davies, R.; De Cesare, A.; Herman, L.; Hilbert, F.; et al. Pathogenicity assessment of Shiga toxin-producing Escherichia coli (STEC) and the public health risk posed by contamination of food with STEC. EFSA J. 2020, 18, e05967. [CrossRef]

2. Launders, N.; Byrne, L.; Jenkins, C.; Harker, K.; Charlett, A.; Adak, G.K. Disease severity of Shiga toxin-producing E. coli O157 and factors influencing the development of typical haemolytic uraemic syndrome: A retrospective cohort study, 2009-2012. BMJ Open 2016, 6, e009933. [CrossRef]

3. Schmid-Hempel, P.; Frank, S.A. Pathogenesis, Virulence, and Infective Dose. PLoS Pathog. 2007, 3, e147. [CrossRef]

4. Bibbal, D.; Loukiadis, E.; Kérourédan, M.; Ferré, F.; Dilasser, F.; Peytavin de Garam, C.; Cartier, P.; Oswald, E.; Gay, E.; Auvray, F.; et al. Prevalence of carriage of Shiga toxin-producing Escherichia coli serotypes O157:H7, O26:H11, O103:H2, O111:H8, and O145:H28 among slaughtered adult cattle in France. Appl. Environ. Microbiol. 2015, 81, 1397-1405. [CrossRef] [PubMed]

5. Sapountzis, P.; Segura, A.; Desvaux, M.; Forano, E. An Overview of the Elusive Passenger in the Gastrointestinal Tract of Cattle: The Shiga Toxin Producing Escherichia coli. Microorganisms 2020, 8, 877. [CrossRef] [PubMed]

6. Stringer, S.C.; George, S.M.; Peck, M.W. Thermal inactivation of Escherichia coli O157:H7. J. Appl. Microbiol. 2000, 88, 79S-89S. [CrossRef] [PubMed]

7. Jubelin, G.; Desvaux, M.; Schüller, S.; Etienne-Mesmin, L.; Muniesa, M.; Blanquet-Diot, S. Modulation of Enterohaemorrhagic Escherichia coli Survival and Virulence in the Human Gastrointestinal Tract. Microorganisms 2018, 6, 115. [CrossRef]

8. Foster, J.W. Escherichia coli acid resistance: Tales of an amateur acidophile. Nat. Rev. Microbiol. 2004, 2, 898-907. [CrossRef] 
9. King, T.; Lucchini, S.; Hinton, J.C.D.; Gobius, K. Transcriptomic analysis of Escherichia coli O157:H7 and K-12 cultures exposed to inorganic and organic acids in stationary phase reveals acidulant- and strain-specific acid tolerance responses. Appl. Environ. Microbiol. 2010, 76, 6514-6528. [CrossRef]

10. Kim, G.-H.; Breidt, F.; Fratamico, P.; Oh, D.-H. Acid Resistance and Molecular Characterization of Escherichia coli O157:H7 and Different Non-O157 Shiga Toxin-Producing E. coli Serogroups. J. Food Sci. 2015, 80, M2257-M2264. [CrossRef]

11. Etienne-Mesmin, L.; Livrelli, V.; Privat, M.; Denis, S.; Cardot, J.-M.; Alric, M.; Blanquet-Diot, S. Effect of a new probiotic Saccharomyces cerevisiae strain on survival of Escherichia coli O157:H7 in a dynamic gastrointestinal model. Appl. Environ. Microbiol. 2011, 77, 1127-1131. [CrossRef] [PubMed]

12. Arroyo-López, F.N.; Blanquet-Diot, S.; Denis, S.; Thévenot, J.; Chalancon, S.; Alric, M.; Rodríguez-Gómez, F.; Romero-Gil, V.; Jiménez-Díaz, R.; Garrido-Fernández, A. Survival of pathogenic and lactobacilli species of fermented olives during simulated human digestion. Front. Microbiol. 2014, 5, 540. [CrossRef] [PubMed]

13. Miszczycha, S.D.; Thévenot, J.; Denis, S.; Callon, C.; Livrelli, V.; Alric, M.; Montel, M.-C.; Blanquet-Diot, S.; Thevenot-Sergentet, D. Survival of Escherichia coli O26:H11 exceeds that of Escherichia coli O157:H7 as assessed by simulated human digestion of contaminated raw milk cheeses. Int. J. Food Microbiol. 2014, 172, 40-48. [CrossRef] [PubMed]

14. Rysman, T.; Van Hecke, T.; Van Poucke, C.; De Smet, S.; Van Royen, G. Protein oxidation and proteolysis during storage and in vitro digestion of pork and beef patties. Food Chem. 2016, 209, 177-184. [CrossRef] [PubMed]

15. Papuc, C.; Goran, G.V.; Predescu, C.N.; Nicorescu, V. Mechanisms of Oxidative Processes in Meat and Toxicity Induced by Postprandial Degradation Products: A Review. Compr. Rev. Food Sci. Food Saf. 2017, 16, 96-123. [CrossRef] [PubMed]

16. de La Pomélie, D.; Santé-Lhoutellier, V.; Sayd, T.; Gatellier, P. Oxidation and nitrosation of meat proteins under gastro-intestinal conditions: Consequences in terms of nutritional and health values of meat. Food Chem. 2018, 243, 295-304. [CrossRef]

17. de La Pomélie, D.; Santé-Lhoutellier, V.; Sayd, T.; Théron, L.; Gatellier, P. Using a dynamic artificial digestive system to investigate heme iron nitrosylation during gastro-intestinal transit. Food Chem. 2019, 281, 231-235. [CrossRef]

18. Sheridan, W.G.; Lowndes, R.H.; Young, H.L. Intraoperative tissue oximetry in the human gastrointestinal tract. Am. J. Surg. 1990, 159, 314-319. [CrossRef]

19. Locato, V.; Cimini, S.; Gara, L.D. Strategies to increase vitamin C in plants: From plant defense perspective to food biofortification. Front. Plant Sci. 2013, 4, 152. [CrossRef]

20. Rosier, B.T.; Moya-Gonzalvez, E.M.; Corell-Escuin, P.; Mira, A. Isolation and Characterization of Nitrate-Reducing Bacteria as Potential Probiotics for Oral and Systemic Health. Front. Microbiol. 2020, 11, 555465. [CrossRef]

21. Thomson, B. Nitrates and nitrites dietary exposure and risk assessment. In ESR Client Report FW0392; New Zealand Food Safety Authority: Wellington, New Zealand, 2004.

22. Kuhnle, G.G.C.; Story, G.W.; Reda, T.; Mani, A.R.; Moore, K.P.; Lunn, J.C.; Bingham, S.A. Diet-induced endogenous formation of nitroso compounds in the GI tract. Free Radic. Biol. Med. 2007, 43, 1040-1047. [CrossRef]

23. Bechaux, J.; de La Pomélie, D.; Théron, L.; Santé-Lhoutellier, V.; Gatellier, P. Iron-catalysed chemistry in the gastrointestinal tract: Mechanisms, kinetics and consequences. A review. Food Chem. 2018, 268, 27-39. [CrossRef] [PubMed]

24. Hoebler, M.-F.; Devaux, A.; Karinthi, C.; Belleville, J.-L.; Barry, C. Particle size of solid food after human mastication and in vitro simulation of oral breakdown. Int. J. Food Sci. Nutr. 2000, 51, 353-366. [CrossRef] [PubMed]

25. Dumas, J.B.A. Procedes de l'analyse organique. Ann. Chim. Phys. 1831, 2, 198.

26. Folch, J.; Lees, M.; Stanley, G.H.S. A simple method for the isolation and purification of total lipids from animal tissues. J. Biol. Chem. 1957, 226, 497-509. [CrossRef]

27. Gobert, A.P.; Vareille, M.; Glasser, A.-L.; Hindré, T.; de Sablet, T.; Martin, C. Shiga Toxin Produced by Enterohemorrhagic Escherichia coli Inhibits PI3K/NF-кB Signaling Pathway in Globotriaosylceramide-3-Negative Human Intestinal Epithelial Cells. J. Immunol. 2007, 178, 8168. [CrossRef] [PubMed]

28. Seo, J.-H.; Park, H.K.; Park, J.S.; Yeom, J.S.; Lim, J.-Y.; Park, C.-H.; Woo, H.-O.; Youn, H.-S.; Jun, J.-S.; Ko, G.-H.; et al. Association between Gastric $\mathrm{pH}$ and Helicobacter pylori Infection in Children. Pediatr. Gastroenterol. Hepatol. Nutr. 2015, 18, 246-252. [CrossRef]

29. Minekus, M.; Alminger, M.; Alvito, P.; Ballance, S.; Bohn, T.; Bourlieu, C.; Carrière, F.; Boutrou, R.; Corredig, M.; Dupont, D.; et al. A standardised static in vitro digestion method suitable for food-An international consensus. Food Funct. 2014, 5, 1113-1124. [CrossRef]

30. Sayd, T.; Peyron, M.-A.; Viet, S.; Santé-Lhoutellier, V. Impact of mastication on the gastric digestion of frankfurters: Case of elderly. In Proceedings of the 62nd International Congress of Meat Science and Technology (ICoMST), Bangkok, Thailand, 14-19 August 2016.

31. Harkouss, R.; Mirade, P.-S.; Gatellier, P. Development of a rapid, specific and efficient procedure for the determination of proteolytic activity in dry-cured ham: Definition of a new proteolysis index. Meat Sci. 2012, 92, 84-88. [CrossRef]

32. Oliver, C.N.; Alin, B.W.; Moerman, E.J.; Goldstein, S.; Stadtman, E.R. Age-related changes in oxidized proteins. J. Biol. Chem. 1987, 262, 5488-5491. [CrossRef]

33. Lynch, S.M.; Frei, B. Mechanisms of copper- and iron-dependent oxidative modification of human low-density lipoprotein. J. Lipid Res. 1993, 34, 1745-1751. [CrossRef]

34. Stolze, K.; Dadak, A.; Liu, Y.; Nohl, H. Hydroxylamine and phenol-induced formation of methemoglobin and free radical intermediates in erythrocytes. Biochem. Pharmacol. 1996, 52, 1821-1829. [CrossRef] 
35. Vislisel, J.M.; Schafer, F.Q.; Buettner, G.R. A simple and sensitive assay for ascorbate using a plate reader. Anal. Biochem. 2007, 365, 31-39. [CrossRef] [PubMed]

36. Bonifacie, A.; Aubry, L.; Gatellier, P.; Santé-Lhoutellier, V.; Théron, L. Determination of nitroso-compounds in food products. MethodsX 2021, 8, 101289. [CrossRef]

37. Hornsey, H.C. The colour of cooked cured pork. I.-Estimation of the Nitric oxide-Haem Pigments. J. Sci. Food Agric. 1956, 7, 534-540. [CrossRef]

38. Bates, D.; Maechler, M.; Bolker, B.; Walker, S. Fitting Linear Mixed-Effects Models Using lme4. J. Stat. Softw. 2015, 67, 1-48. [CrossRef]

39. Russell, V. Lenth Emmeans: Estimated Marginal Means, Aka Least-Squares Means. R Package Version 1.6.3. 2021. Available online: https: / /CRAN.R-project.org/package=emmeans (accessed on 1 September 2021).

40. Bax, M.-L.; Buffière, C.; Hafnaoui, N.; Gaudichon, C.; Savary-Auzeloux, I.; Dardevet, D.; Santé-Lhoutellier, V.; Rémond, D. Effects of Meat Cooking, and of Ingested Amount, on Protein Digestion Speed and Entry of Residual Proteins into the Colon: A Study in Minipigs. PLoS ONE 2013, 8, e61252. [CrossRef] [PubMed]

41. Gobert, M.; Rémond, D.; Loonis, M.; Buffière, C.; Santé-Lhoutellier, V.; Dufour, C. Fruits, vegetables and their polyphenols protect dietary lipids from oxidation during gastric digestion. Food Funct. 2014, 5, 2166-2174. [CrossRef]

42. Sicard, J.; Mirade, P.-S.; Portanguen, S.; Clerjon, S.; Kondjoyan, A. Simulation of the gastric digestion of proteins of meat bolus using a reaction-diffusion model. Food Funct. 2018, 9, 6455-6469. [CrossRef] [PubMed]

43. Mennah-Govela, Y.A.; Singh, R.P.; Bornhorst, G.M. Buffering capacity of protein-based model food systems in the context of gastric digestion. Food Funct. 2019, 10, 6074-6087. [CrossRef]

44. Hamosh, M.; Henderson, T.R.; Hamosh, P. Gastric Lipase and Pepsin Activities in the Developing Ferret: Nonparallel Development of the Two Gastric Digestive Enzymes. J. Pediatr. Gastroenterol. Nutr. 1998, 26, 162-166. [CrossRef]

45. Large, T.M.; Walk, S.T.; Whittam, T.S. Variation in Acid Resistance among Shiga Toxin-Producing Clones of Pathogenic Escherichia coli. Appl. Environ. Microbiol. 2005, 71, 2493-2500. [CrossRef] [PubMed]

46. Peng, S.; Tasara, T.; Hummerjohann, J.; Stephan, R. An Overview of Molecular Stress Response Mechanisms in Escherichia coli Contributing to Survival of Shiga Toxin-Producing Escherichia coli during Raw Milk Cheese Production. J. Food Protect. 2011, 74, 849-864. [CrossRef] [PubMed]

47. Thanassi, D.G.; Cheng, L.W.; Nikaido, H. Active efflux of bile salts by Escherichia coli. J. Bacteriol. 1997, 179, 2512-2518. [CrossRef] [PubMed]

48. Begley, M.; Gahan, C.G.M.; Hill, C. The interaction between bacteria and bile. FEMS Microbiol. Rev. 2005, 29, 625-651. [CrossRef]

49. Hamner, S.; McInnerney, K.; Williamson, K.; Franklin, M.J.; Ford, T.E.E. Bile Salts Affect Expression of Escherichia coli O157:H7 Genes for Virulence and Iron Acquisition, and Promote Growth under Iron Limiting Conditions. PLoS ONE 2013, 8, e74647. [CrossRef] [PubMed]

50. Kandell, R.L.; Bernstein, C. Bile salt/acid induction of DNA damage in bacterial and mammalian cells: Implications for co-lon cancer. Nut. Cancer 1991, 16, 227-238. [CrossRef]

51. Kus, J.V.; Gebremedhin, A.; Dang, V.; Tran, S.-L.; Serbanescu, A.; Barnett Foster, D. Bile salts induce resistance to polymyxin in enterohemorrhagic Escherichia coli O157:H7. J. Bacteriol. 2011, 193, 4509-4515. [CrossRef]

52. Majou, D.; Christieans, S. Mechanisms of the bactericidal effects of nitrate and nitrite in cured meats. Meat Sci. 2018, 145, 273-284 [CrossRef]

53. Casey, P.; Condon, S. Synergistic lethal combination of nitrite and acid pH on a verotoxin-negative strain of Escherichia coli O157. Int. J. Food Microbiol. 2000, 55, 255-258. [CrossRef]

54. Gardner, A.M.; Helmick, R.A.; Gardner, P.R. Flavorubredoxin, an inducible catalyst for nitric oxide reduction and detoxification in Escherichia coli. J. Biol. Chem. 2002, 277, 8172-8177. [CrossRef]

55. Gomes, C.M.; Giuffrè, A.; Forte, E.; Vicente, J.B.; Saraiva, L.M.; Brunori, M.; Teixeira, M. A Novel Type of Nitric-oxide Reductase: Escherichia coli flavorubredoxin *. J. Biol. Chem. 2002, 277, 25273-25276. [CrossRef] [PubMed]

56. van Wonderen, J.H.; Burlat, B.; Richardson, D.J.; Cheesman, M.R.; Butt, J.N. The Nitric Oxide Reductase Activity of Cytochrome c Nitrite Reductase from Escherichia coli *. J. Biol. Chem. 2008, 283, 9587-9594. [CrossRef] [PubMed]

57. Vine, C.E.; Cole, J.A. Nitrosative stress in Escherichia coli: Reduction of nitric oxide. Biochem. Soc. Trans. 2011, 39, 213-215. [CrossRef] [PubMed]

58. Hoppler, M.; Schönbächler, A.; Meile, L.; Hurrell, R.F.; Walczyk, T. Ferritin-Iron Is Released during Boiling and In Vitro Gastric Digestion. J. Nutr. 2008, 138, 878-884. [CrossRef] [PubMed]

59. Bradley, J.M.; Svistunenko, D.A.; Wilson, M.T.; Hemmings, A.M.; Moore, G.R.; Le Brun, N.E. Bacterial iron detoxification at the molecular level. J. Biol. Chem. 2020, 295, 17602-17623. [CrossRef]

60. Lau, C.K.Y.; Ishida, H.; Liu, Z.; Vogel, H.J. Solution structure of Escherichia coli FeoA and its potential role in bacterial ferrous iron transport. J. Bacteriol. 2013, 195, 46-55. [CrossRef] [PubMed]

61. Honikel, K.-O. The use and control of nitrate and nitrite for the processing of meat products. Meat Sci. 2008, 78, 68-76. [CrossRef]

62. Bonifacie, A.; Promeyrat, A.; Nassy, G.; Gatellier, P.; Santé-Lhoutellier, V.; Théron, L. Chemical reactivity of nitrite and ascorbate in a cured and cooked meat model implication in nitrosation, nitrosylation and oxidation. Food Chem. 2021, 348, 129073. [CrossRef] [PubMed] 
63. Nagababu, E.; Rifkind, J.M. Routes for Formation of S-Nitrosothiols in Blood. Cell Biochem. Biophys. 2013, 67, 385-398. [CrossRef] [PubMed]

64. Gyaneshwar, P.; Paliy, O.; McAuliffe, J.; Popham, D.L.; Jordan, M.I.; Kustu, S. Sulfur and nitrogen limitation in Escherichia coli K-12: Specific homeostatic responses. J. Bacteriol. 2005, 187, 1074-1090. [CrossRef] [PubMed]

65. Gu, J.; Lewis, R.S. Effect of $\mathrm{pH}$ and Metal Ions on the Decomposition Rate of S-nitrosocysteine. Ann. Biomed. Eng. 2007, 35, 1554-1560. [CrossRef] [PubMed]

66. de La Pomélie, D.; Santé-Lhoutellier, V.; Gatellier, P. Mechanisms and kinetics of tryptophan N-nitrosation in a gastro-intestinal model. Food Chem. 2017, 218, 487-495. [CrossRef] [PubMed] 